\title{
Effects of Feed Composition and Feed Impurities in the Catalytic Conversion of Syngas to Higher Alcohols over Alkali-Promoted Cobalt-Molybdenum Sulfide
}

\author{
Christensen, Jakob Munkholt; Jensen, Peter Arendt; Jensen, Anker Degn
}

Published in:

Industrial \& Engineering Chemistry Research

Link to article, DOI:

10.1021/ie200235e

Publication date:

2011

Document Version

Publisher's PDF, also known as Version of record

Link back to DTU Orbit

Citation (APA):

Christensen, J. M., Jensen, P. A., \& Jensen, A. D. (2011). Effects of Feed Composition and Feed Impurities in the Catalytic Conversion of Syngas to Higher Alcohols over Alkali-Promoted Cobalt-Molybdenum Sulfide. Industrial \& Engineering Chemistry Research, 50(13), 7949-7963. https://doi.org/10.1021/ie200235e

\section{General rights}

Copyright and moral rights for the publications made accessible in the public portal are retained by the authors and/or other copyright owners and it is a condition of accessing publications that users recognise and abide by the legal requirements associated with these rights.

- Users may download and print one copy of any publication from the public portal for the purpose of private study or research.

- You may not further distribute the material or use it for any profit-making activity or commercial gain

- You may freely distribute the URL identifying the publication in the public portal 


\title{
Effects of Feed Composition and Feed Impurities in the Catalytic Conversion of Syngas to Higher Alcohols over Alkali-Promoted Cobalt-Molybdenum Sulfide
}

\author{
Jakob M. Christensen, Peter A. Jensen, and Anker D. Jensen* \\ Department of Chemical and Biochemical Engineering, Technical University of Denmark, Søltofts Plads, Building 229,
} 2800 Kongens Lyngby, Denmark

\begin{abstract}
Alkali-promoted cobalt-molybdenum sulfide is a potential catalyst for the conversion of syngas into higher alcohols. This work is an investigation of how the feed composition influences the behavior of the sulfide catalyst. In a sulfur-free syngas the production of higher alcohols is observed to be optimal with an equimolar mixture of $\mathrm{CO}$ and $\mathrm{H}_{2}$ in the feed, while the methanol production benefits from an increasing hydrogen content in the feed. The influence of $\mathrm{NH}_{3}$ and $\mathrm{H}_{2} \mathrm{O}$ in the syngas feed has also been investigated. Ammonia (741 ppmv) in the feed is observed to cause a general and largely reversible deactivation of the catalyst. Operation with elevated water levels in the syngas feed $(4.7-13.4 \mathrm{~mol} \%)$ is observed to cause a deactivation of the catalyst, and it is especially the chain growth that is affected.
\end{abstract}

\section{INTRODUCTION}

Gasification of biomass, coal, and carbon containing waste fractions to form syngas followed by a catalytic conversion of the syngas into alcohols is a possible route to synthetic fuels or fuel additives. Due to their high octane numbers alcohols are interesting as gasoline additives/replacements. ${ }^{1-3}$ A mixture of methanol or ethanol with higher alcohols has a better gasoline miscibility than pure methanol or ethanol, because the higher alcohols act as cosolvents and stabilize the mixture. ${ }^{2,4,5}$ Compared to pure methanol, a mixture containing methanol and higher alcohols can therefore more easily be introduced into the existing fuel infrastructure. Such a mixture of methanol and higher alcohols can be formed directly from syngas over various catalytic systems. Among these systems are alkali/Cu, ${ }^{1,6-8} \mathrm{Co} / \mathrm{Cu},{ }^{9-11} \mathrm{Rh},{ }^{12,13}$ alkali/ $\mathrm{ZnO} / \mathrm{Cr}_{2} \mathrm{O}_{3},{ }^{14-17}$ and alkali/ $\mathrm{MoS}_{2} \cdot{ }^{18-20}$ Important reactions that occur over the alcohol synthesis catalysts are methanol synthesis (R1), higher alcohol synthesis (R2), alkane synthesis (R3), and the water gas shift reaction (R4):

$$
\begin{gathered}
\mathrm{CO}+2 \mathrm{H}_{2} \rightleftharpoons \mathrm{CH}_{3} \mathrm{OH} \\
n \mathrm{CO}+2 n \mathrm{H}_{2} \rightleftharpoons \mathrm{C}_{n} \mathrm{H}_{2 n+1} \mathrm{OH}+(n-1) \mathrm{H}_{2} \mathrm{O}, n \geq 2 \\
n \mathrm{CO}+(2 n+1) \mathrm{H}_{2} \rightleftharpoons \mathrm{C}_{n} \mathrm{H}_{2 n+2}+n \mathrm{H}_{2} \mathrm{O} \\
\mathrm{CO}+\mathrm{H}_{2} \mathrm{O} \rightleftharpoons \mathrm{H}_{2}+\mathrm{CO}_{2}
\end{gathered}
$$

The catalytic system, which is studied in this work, is potassium promoted cobalt - molybdenum sulfide on a carbon support. For syngas conversion it has previously been determined that addition of alkali salts to $\mathrm{MoS}_{2}$ shifts the selectivity from hydrocarbons to alcohols, and that addition of Co to alkali/ $\mathrm{MoS}_{2}$ catalysts shifts the product distribution toward the desirable higher alcohols. ${ }^{19}$ Alkali promoted cobalt-molybdenum sulfide has previously been shown to yield a good alcohol selectivity-even at a fairly high CO conversion. ${ }^{19,21,22}$ An argument that has also often been made in favor of the sulfide catalyst is that the sulfide in comparison to other potential catalysts is more tolerant toward sulfur species in the syngas. ${ }^{19,23-26}$ It has been suggested that this sulfur tolerance may enable the user to employ a less thorough and therefore less costly removal of sulfur from the syngas. ${ }^{27}$ While much attention has been paid to the sulfur resistance of the sulfide catalyst, less work has been carried out to determine how the syngas composition will influence the catalytic activity and how feed impurities other than sulfur species will affect the properties of the sulfide catalyst. Such investigations could help to clarify to what extent cleaning and conditioning of the syngas is needed for the sulfide catalyst.

The topic of this work is how the composition of the syngas feed influences the catalytic properties. It is investigated what bearing the water content in the syngas has on the catalytic properties, how an $\mathrm{NH}_{3}$ impurity in the syngas affects the activity of the sulfide, and how the $\mathrm{H}_{2} / \mathrm{CO}$ ratio in a sulfur-free syngas influences the catalytic properties.

Table 1 summarizes several reported syngas compositions for various gasification processes. Table 1 illustrates that the gasifier type and the feedstock have a significant impact upon the syngas composition. It is therefore only possible to provide a general approximation of the typical $\mathrm{H}_{2} / \mathrm{CO}$ ratio in the raw syngas. Biomass gasification generally results in an $\mathrm{H}_{2} / \mathrm{CO}$ ratio on the order of $1,{ }^{30,31}$ while coal gasification often results in a lower $\mathrm{H}_{2} / \mathrm{CO}$ ratio. ${ }^{32}$ As seen for the Lurgi moving bed gasifier in Table 1 , there are, however, exceptions to these guidelines. Given the wide variation in the $\mathrm{H}_{2} / \mathrm{CO}$ ratios for the gasification processes illustrated in Table 1 , it could be important to establish how the $\mathrm{H}_{2} / \mathrm{CO}$ ratio influences the activity of the catalyst.

Received: February 3, 2011

Accepted: $\quad$ May 26, 2011

Revised: April 21, 2011

Published: May 26, 2011 
Table 1. Reported Wet Syngas Compositions for Various Gasification Processes

\begin{tabular}{|c|c|c|c|c|c|}
\hline $\begin{array}{l}\text { gasifier design } \\
\text { type }\end{array}$ & $\begin{array}{l}\text { Lurgi } \\
\text { moving bed }\end{array}$ & $\begin{array}{l}\text { Texaco } \\
\text { entrained flow }\end{array}$ & $\begin{array}{l}\text { Shell } \\
\text { entrained flow }\end{array}$ & $\begin{array}{l}\text { Shell }^{a} \\
\text { entrained flow }\end{array}$ & $\begin{array}{l}\text { IGT } \\
\text { fluidized bed }\end{array}$ \\
\hline fuel & coal & coal & coal & biomass & biomass \\
\hline oxidant & $\mathrm{O}_{2}$ & $\mathrm{O}_{2}$ & $\mathrm{O}_{2}$ & $\mathrm{O}_{2}$ & $\mathrm{O}_{2}$ \\
\hline gasification agent & $\mathrm{H}_{2} \mathrm{O}$ & $\mathrm{H}_{2} \mathrm{O}$ & $\mathrm{H}_{2} \mathrm{O}$ & $\mathrm{H}_{2} \mathrm{O}$ & $\mathrm{H}_{2} \mathrm{O}$ \\
\hline exit temperature $\left[{ }^{\circ} \mathrm{C}\right]$ & $540^{b}$ & $1315^{b}$ & 1427 & 1085 & 982 \\
\hline pressure [bar] & & & & 24.3 & 34 \\
\hline $\mathrm{H}_{2} \mathrm{O}[\mathrm{vol} \%]$ & 50 & 17 & 2.01 & 18.4 & 31.8 \\
\hline $\mathrm{H}_{2}[\mathrm{vol} \%]$ & 21 & 29.6 & 26.8 & 30.7 & 20.8 \\
\hline $\mathrm{CO}[\mathrm{vol} \%]$ & 8 & 41 & 63.1 & 39.0 & 15.0 \\
\hline $\mathrm{CO}_{2}[\mathrm{vol} \%]$ & 15 & 10 & 1.5 & 11.8 & 23.9 \\
\hline $\mathrm{CH}_{4}[\mathrm{vol} \%]$ & 4.2 & 0.3 & 0.0 & 0.1 & 8.2 \\
\hline $\mathrm{C}_{2+}{ }^{c}[\mathrm{vol} \%]$ & 0.5 & 0 & 0 & 0 & 0.3 \\
\hline $\mathrm{H}_{2} \mathrm{~S}+\mathrm{COS}[\mathrm{vol} \%]$ & 0.7 & 1.1 & 1.4 & & \\
\hline $\mathrm{NH}_{3}[\mathrm{vol} \%]$ & 0.4 & 0.2 & & & \\
\hline $\mathrm{N}_{2}[\mathrm{vol} \%]$ & 0.2 & 0.8 & 4.08 & & 0.4 \\
\hline $\mathrm{H}_{2} / \mathrm{CO}[\mathrm{mol} / \mathrm{mol}]$ & 2.78 & 0.72 & 0.49 & 0.79 & 1.39 \\
\hline reference & 28 & 28 & 29 & 30 & 31 \\
\hline
\end{tabular}

${ }^{a}$ This syngas composition is calculated through an assumption of chemical equilibrium. ${ }^{b}$ These temperatures are reported as operating temperatures.

${ }^{c}$ The fraction of $\mathrm{C}_{2+}$ species in the syngas.

The data in Table 1 illustrate that coal gasification can yield a syngas with significant levels of sulfur-containing compounds. For biomass gasification the sulfur content in the syngas is typically markedly lower than that for coal gasification. For gasification of wood and straw the total content of sulfur species of the synthesis gas is typically below $200 \mathrm{ppmv}$, although some crops can yield slightly higher sulfur contents. ${ }^{33-35}$ Hydrogen sulfide is the dominant sulfur species in the syngas. For high temperature gasification processes all the sulfur is essentially present as $\mathrm{H}_{2} \mathrm{~S}$ or COS, and here $93-96 \%$ of the sulfur is under typical conditions present as $\mathrm{H}_{2} \mathrm{~S} .{ }^{33}$ For a raw syngas derived from coal gasification in a Lurgi moving bed gasifier, Supp ${ }^{36}$ also reports that $95 \mathrm{~mol} \%$ of the sulfur is present in the form of $\mathrm{H}_{2} \mathrm{~S}$. Hydrogen sulfide is therefore also used as the representative sulfur compound in the present investigations. The sulfide catalyst is able to operate both with and without sulfur in the syngas. ${ }^{19,37,38}$ While the presence of a sulfur source like $\mathrm{H}_{2} \mathrm{~S}$ in the syngas will not necessarily quell the activity of the catalyst, the presence of $\mathrm{H}_{2} \mathrm{~S}$ can nevertheless have a pronounced impact upon the catalytic properties. The presence of $\mathrm{H}_{2} \mathrm{~S}$ in the syngas shifts the selectivity from alcohols to hydrocarbons by promoting the hydrocarbon production rate, ${ }^{37}$ and the presence of $\mathrm{H}_{2} \mathrm{~S}$ in the syngas can lead to the incorporation of significant amounts of sulfur species into the alcohol product. ${ }^{37}$ The sulfur species incorporated into the alcohol product are primarily the thiols corresponding to the formed alcohols. ${ }^{37}$ For supported $\mathrm{K}_{2} \mathrm{CO}_{3} /$ $\mathrm{Co} / \mathrm{MoS}_{2} / \mathrm{C}$ catalysts operated in a sulfur-free or sulfur-poor syngas, it has been observed that there is a gradual decline in the fraction of higher alcohols in the alcohol product. ${ }^{37,38}$ This decline in the fraction of higher alcohols continues for at least the first $30-40 \mathrm{~h}$ that the catalyst is on stream, although the rate of the decline gradually slows down. At higher $\mathrm{H}_{2} \mathrm{~S}$ levels in the syngas feed the product distribution is stabilized, and the production rates of the higher alcohols are generally improved. ${ }^{37}$ We have previously, with a catalyst and conditions similar to those presently employed, observed that the $\mathrm{H}_{2} \mathrm{~S}$ level necessary to stabilize the product distribution was found in the 57-103 ppmv range. ${ }^{37}$ For unsupported cobalt-molybdenum sulfide catalysts it has also been observed that the alcohol distribution changes in a sulfur-free syngas, since the methanol production gradually increases over the first $50-100 \mathrm{~h}$ and then stabilizes. ${ }^{39}$ Because of the negative effects of $\mathrm{H}_{2} \mathrm{~S}$ in the syngas, i.e., the incorporation of sulfur species into the alcohol product, the focus in the current investigations is the use of a sulfur-free syngas. In some cases the studies are, however, augmented with investigations carried out in the presence of $\mathrm{H}_{2} \mathrm{~S}$. In these cases the $\mathrm{H}_{2} \mathrm{~S}$ content employed is higher than the 103 ppmv that previously has been observed to stabilize the product distribution.

The ammonia content in the raw syngas from the gasifier will depend upon the feedstock, the process conditions, and the type of gasifier employed in the gasification process. It is therefore only possible to provide some general levels for the nitrogen compounds in the syngas. Coal gasification typically results in a syngas with $10^{3}-10^{4}$ ppmv $\mathrm{NH}_{3}$ and a few hundred parts per million by volume HCN. ${ }^{28,40}$ Wood gasification generally results in lower nitrogen levels in the syngas-often 100-1000 ppmv $\mathrm{NH}_{3}$ and $10-100$ ppmv HCN. ${ }^{40,41}$ Some nitrogen-rich crops (e.g., alfalfa) can, however, yield higher ammonia contents in the syngas-even values in the $1-2 \mathrm{vol} \%$ range. ${ }^{34,35}$ It would be interesting to determine how these levels of $\mathrm{NH}_{3}$ could influence the activity of the sulfide catalyst.

Table 1 also illustrates that the raw syngas from the gasifier contains considerable amounts of water and $\mathrm{CO}_{2}$. Water and $\mathrm{CO}_{2}$ are also formed as byproducts in the synthesis reactions. The sulfided alcohol synthesis catalyst has a significant activity in the water gas shift reaction, ${ }^{25}$ and water and $\mathrm{CO}_{2}$ are therefore largely parallel products in the alcohol synthesis reactor. In this work the effect that the water content in the syngas feed has upon the catalytic properties is evaluated, and the observed effect of water is compared to previous investigations of the role of $\mathrm{CO}_{2}$ in syngas.

\section{EXPERIMENTAL SECTION}

This work has been performed using a $\mathrm{K}_{2} \mathrm{CO}_{3} / \mathrm{Co} / \mathrm{MoS}_{2} / \mathrm{C}$ catalyst (13.60 wt \% Mo, 2.71 wt \% Co, 9.0 wt \% K; BET area 


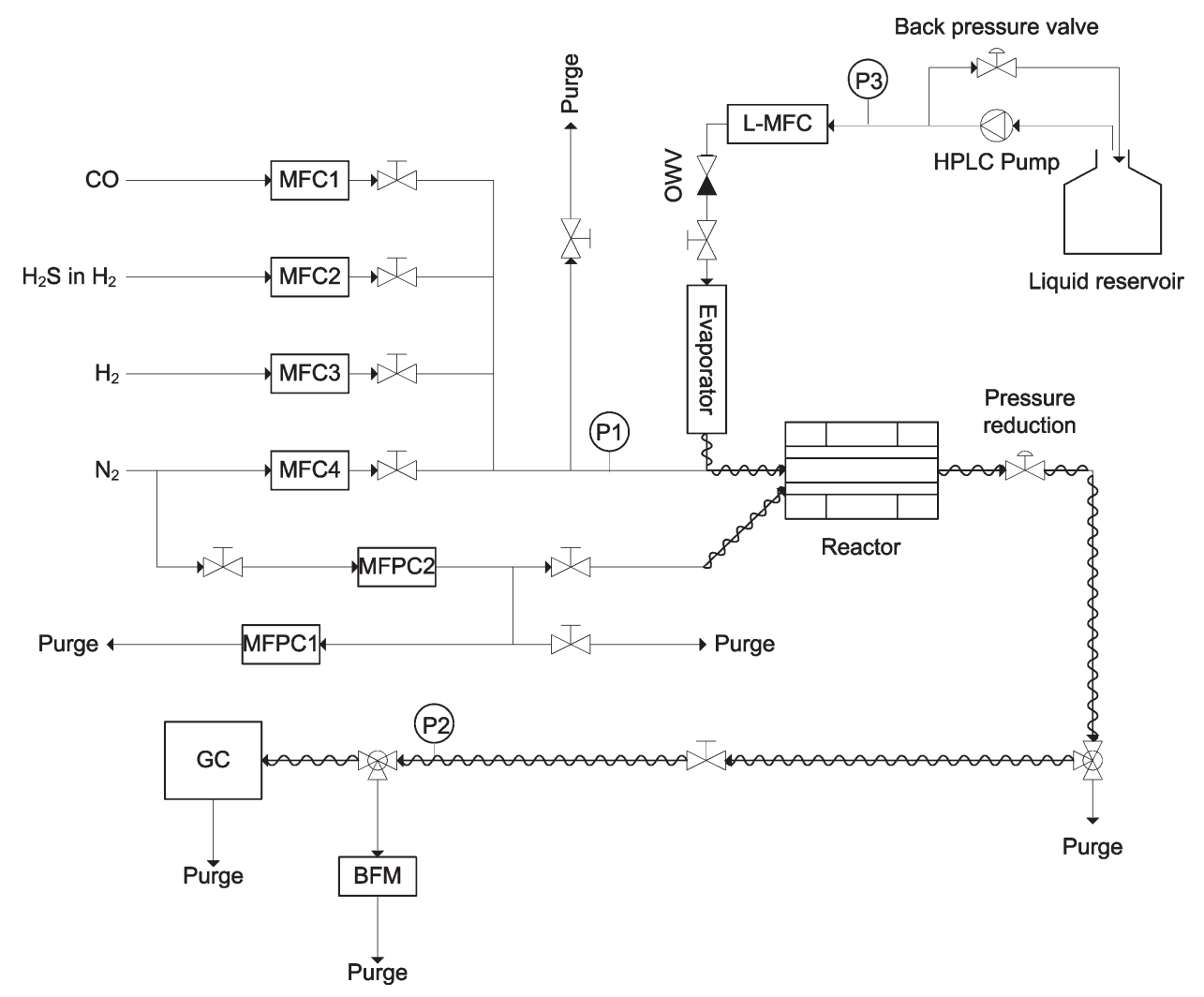

Figure 1. Simplified diagram illustrating the experimental setup. BFM, bubble flow meter; GC, gas chromatograph; L-MFC, mass flow controller for liquids; $\mathrm{MF}(\mathrm{P}) \mathrm{C}$, mass flow (pressure) controller; OWV, one-way valve; $\mathrm{P}$, manometer. Heat tracing tubing is indicated by sinusoidal curves. In a few of

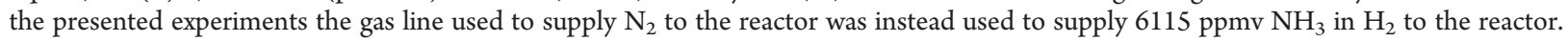

$526 \mathrm{~m}^{2} / \mathrm{g} ; d_{\mathrm{p}, \mathrm{avg}}=1.4 \mathrm{~mm}$ ) with Daihope carbon as the support. The catalyst has been provided by Haldor Topsøe A/S. Previous results obtained with this catalyst have been reported elsewhere. ${ }^{37,42}$ Prior to use the catalyst has been sulfided in a flow of $2 \mathrm{~mol} \% \mathrm{H}_{2} \mathrm{~S}$ in $\mathrm{H}_{2}$. In the sulfidation the reactor was purged with nitrogen, and the temperature was increased to $100^{\circ} \mathrm{C}$. The catalyst was then at atmospheric pressure exposed to an $80 \mathrm{NmL} /$ min (with $\mathrm{NmL}$ relating to $273.15 \mathrm{~K}$ and $1 \mathrm{~atm}$ ) flow of $2 \mathrm{~mol} \%$ $\mathrm{H}_{2} \mathrm{~S}$ in $\mathrm{H}_{2}$, and the temperature was increased at a rate of $3{ }^{\circ} \mathrm{C} / \mathrm{min}$ to the reaction temperature of $325^{\circ} \mathrm{C}$. The sulfidation was maintained at the final temperature for approximately $15 \mathrm{~h}$. At that point no further sulfur uptake was observed. No characterization studies were performed on fresh or spent catalyst samples.

$\mathrm{CO}$ hydrogenation experiments were conducted in a high pressure flow reactor setup. Figure 1 shows a simplified diagram of the experimental setup. Detailed descriptions of the experimental setup and the experimental procedure have been provided elsewhere. ${ }^{37,42,43} \mathrm{~A}$ bed of catalyst particles (7-9 g, $\sim 12.6 \mathrm{~cm}^{3}$ ) was placed in a quartz tube contained inside a stainless steel pressure shell. As the inside of the quartz tube is pressurized, nitrogen is dosed to the surrounding pressure shell to ensure an equal pressure on both sides of the quartz tube wall. This arrangement should enable the investigation of high pressure reactions with little influence from catalytic activity of the reactor wall. The reactor temperature is monitored by a K-type thermo element, which is located in a stainless steel thermo pocket inside the pressure shell. The thermo pocket for part of its extent touches the outside of the quartz tube. The reported temperature for a given experiment is the average of the temperature along the catalyst bed, and the temperature along the bed is generally within $1{ }^{\circ} \mathrm{C}$ of the average value. The pressure shell is located horizontally inside an Entech tube oven, which provides the relevant reaction temperature. Gases $\left(\geq 99.999 \% \mathrm{H}_{2}, \geq 99.97 \%\right.$ $\mathrm{CO}, \geq 99.97 \% \mathrm{~N}_{2}, 2 \mathrm{~mol} \% \mathrm{H}_{2} \mathrm{~S}$ in $\mathrm{H}_{2}$, and 6115 ppmv $\mathrm{NH}_{3}$ in $\mathrm{H}_{2}$ ) are supplied from pressurized cylinders via Brooks 5850S mass flow controllers.

Normally liquid components are supplied to the reactor via a special liquid feeding system. An HPLC pump (Knauer K-120, $0-10 \mathrm{~mL} / \mathrm{min}$ ), which draws the liquid from a feed reservoir, pressurizes the liquid. The pressure in the feeding section is controlled by a back-pressure valve (Tescom 26-1764-24-154) that directs part of the liquid flow back into the feed reservoir. The liquid flow to the reactor is controlled by a Brooks Flomega 5881 mass flow controller $\left(0-15 \mathrm{~g}\right.$ of $\left.\mathrm{H}_{2} \mathrm{O} / \mathrm{h}\right)$. The controlled liquid flow is evaporated in a custom-made evaporator. In the evaporator the liquid/vapor flows through a $4.45 \mathrm{~m}$ steel tube ( $1 / 8$ in.), which is coiled around a hollow copper rod (outer diameter $20 \mathrm{~mm}$ ). The heating for the evaporation is supplied by a heating cartridge $(500 \mathrm{~W})$ that fits exactly into the hollow copper rod. After the evaporator the vaporized component is mixed with the incoming gaseous feed. The tubing between the evaporator and the reactor entrance is wrapped in heat tracing tapes to avoid condensation of liquid in the tubes. The temperatures of the evaporator and of the heat tracing cables are regulated by Eurotherm controllers and monitored by type-K thermo elements. The water co-fed with syngas is ultrapure, distilled water (resistivity $18.2 \mathrm{M} \Omega \cdot \mathrm{cm}$ ) that has been prepared using an Elgastat Maxima Analytical water purification system. 
Product characterization downstream from the reactor has been conducted using a GC-FID/TCD detection system. The oxygenates characterized in these experiments are methanol, ethanol, 1-propanol, and 1-butanol as well as isobutyl alcohol, dimethyl ether, and ethyl acetate. Characterized hydrocarbons are methane, ethane, ethene, and propane. For gaseous compounds the GC peak areas have been related to concentrations by calibration against certified gas mixtures ( $\pm 2 \%$ from AGA A/S $)$. For normally liquid compounds the calibrations have been made against gas mixtures prepared by injection of a known quantity of the liquid component into a known volume of nitrogen in a Tedlar bag and allowing the liquid to evaporate. The product characterization relied on online GC analyses. No experiments were performed with condensation and analysis of the liquid alcohol product. We have, as mentioned in the Introduction, previously observed ${ }^{37}$ that the use of a sulfide catalyst leads to incorporation of sulfur species (thiols, dimethyl sulfide, and in some cases even thiophenes) into the condensed alcohol product. In the present experiments with addition of $\mathrm{NH}_{3}$ to the syngas there is the added possibility that nitrogen compounds (for example, amines) are incorporated into the alcohol product, but this has not been investigated in the present work.

The downstream tubing is heated by means of heat tracing tapes to avoid condensation of the reaction products. The gas flow rate is measured downstream from the reactor with a soap film, bubble flow meter operating at ambient temperature and pressure.

The measured volumetric flow rate and the measured concentration of component $i$ can be used to determine the molar flow rate of component $i$, which is denoted $F_{i}$. The reported $\mathrm{CO}$ conversion $\left(X_{\mathrm{CO}}\right)$ is calculated from the molar flow rates of $\mathrm{CO}$ into and out of the reactor:

$$
X_{\mathrm{CO}}=\frac{F_{\mathrm{CO}}^{\text {in }}-F_{\mathrm{CO}}^{\text {out }}}{F_{\mathrm{CO}}^{\text {in }}}
$$

In these experiments the mass balances for $\mathrm{C}, \mathrm{O}$, and $\mathrm{H}$ are fulfilled to within $5 \mathrm{~mol} \%$ and typically better than this.

In certain cases calculations have been made on the methanol synthesis equilibrium at the end of the reactor. To account for nonideality in the gas phase at the high reaction pressure, the fugacity coefficients of the involved components have been determined using the Soave-Redlich-Kwong (SRK) equation of state. ${ }^{44,45}$ The evaluation of the fugacity coefficients is based upon a random mixing approximation with all binary interaction parameters assumed to be $0 .{ }^{46}$ In this calculation the $\mathrm{H}_{2} \mathrm{O}$ content in the gas is estimated through an assumption of equilibrium for the water gas shift reaction, but this assumption is not found to have a large impact on the calculated set of fugacity coefficients. The SRK equation of state is used, since it previously has been reported to provide the best description of the methanol synthesis equilibrium at conditions similar to those presently employed. ${ }^{47}$ The critical properties and acentric factors used in the calculations are presented in Table 2.

If the standard state is chosen to be an ideal gas at $1 \mathrm{bar}$, the fugacity-based equilibrium constant for a reaction like the methanol synthesis (R1) can be expressed in the following way: ${ }^{46}$

$$
\frac{f_{\mathrm{MeOH}}}{f_{\mathrm{H}_{2}}{ }^{2} f_{\mathrm{CO}}}=\exp \left(-\frac{\Delta G_{\mathrm{R} 1, T}^{\circ}}{R T}\right)=K_{f} \Leftrightarrow \frac{f_{\mathrm{MeOH}}}{K_{f} f_{\mathrm{H}_{2}}{ }^{2} f_{\mathrm{CO}}}=1
$$

Here $f_{i}$ is the fugacity of component $i$, which can be expressed in terms of the total pressure, $P$, the molar fraction of component
Table 2. Critical Properties $\left(P_{\mathrm{C}}, T_{\mathrm{C}}\right)$ and Acentric Factors $(\omega)$ Used in This Work

\begin{tabular}{lcccc} 
component & $T_{\mathrm{C}}[\mathrm{K}]$ & $P_{\mathrm{C}}[\mathrm{bar}]$ & $\omega$ & ref \\
$\mathrm{N}_{2}$ & 126.21 & 33.9 & 0.038 & 48,49 \\
$\mathrm{H}_{2}$ & 32.97 & 12.93 & -0.22 & 49,50 \\
$\mathrm{CO}$ & 132.91 & 34.99 & 0.049 & 49,50 \\
$\mathrm{CO}_{2}$ & 304.14 & 73.75 & 0.225 & 49,50 \\
$\mathrm{CH}_{4}$ & 190.56 & 45.99 & 0.012 & 48,49 \\
$\mathrm{C}_{2} \mathrm{H}_{4}$ & 282.34 & 50.41 & 0.085 & 49,50 \\
$\mathrm{C}_{2} \mathrm{H}_{6}$ & 305.32 & 48.72 & 0.098 & 49,50 \\
$\mathrm{C}_{3} \mathrm{H}_{8}$ & 369.83 & 42.48 & 0.152 & $49-51$ \\
$\mathrm{H}_{2} \mathrm{O}$ & 647.14 & 220.6 & 0.344 & $49,51,52$ \\
$\mathrm{H}_{2} \mathrm{~S}$ & 373.2 & 89.4 & 0.1 & 49,51 \\
$\mathrm{MeOH}$ & 512.5 & 80.84 & 0.572 & 49,52 \\
EtOH & 514.0 & 61.37 & 0.635 & 49,52 \\
$1-\mathrm{PrOH}$ & 536.8 & 51.69 & 0.625 & 49,52 \\
$1-\mathrm{BuOH}$ & 563.0 & 44.14 & 0.59 & 49,52 \\
iso-BuOH & 547.8 & 42.95 & 0.589 & 46,49 \\
\hline
\end{tabular}

$i, y_{i}$, and the fugacity coefficient of component $i, \varphi_{i}$ :

$$
f_{i}=\varphi_{i} y_{i} P
$$

The fugacity coefficients are calculated on the basis of the measured effluent gas composition and the known temperature and pressure. When the partial pressure of methanol has not reached its equilibrium value, one will have $f_{\mathrm{MeOH}} /\left(K_{f} f_{\mathrm{H}_{2}}{ }^{2} f_{\mathrm{CO}}\right)<1$, and the quantity $f_{\mathrm{MeOH}} /\left(K_{f} f_{\mathrm{H}_{2}}{ }^{2} f_{\mathrm{CO}}\right)$ can thus be used to provide a measure of the degree of equilibration for the methanol synthesis in a given experiment.

\section{RESULTS AND DISCUSSION}

3.1. Role of the $\mathrm{H}_{2} / \mathrm{CO}$ Ratio. The first part of the present investigations concerns the influence of the $\mathrm{H}_{2} / \mathrm{CO}$ ratio in the feed, when the sulfide catalyst is operated in a sulfur-free syngas. In the Introduction it is described how the fraction of higher alcohols decreases over time during operation in a sulfur-free syngas. The variations in the $\mathrm{H}_{2} / \mathrm{CO}$ ratio are therefore not commenced until the catalyst has been given an initiation period of $48 \mathrm{~h}$ at the conditions provided in the caption of Figure 2. Figure 2 shows the production rates of alcohols and hydrocarbons in an $\mathrm{H}_{2} / \mathrm{CO}=0.96 \mathrm{~mol} / \mathrm{mol}$ feed during various stages of the experiment.

Figure 2 shows that the total alcohol production stabilizes, but this covers the fact that the methanol production gradually increases at the expense of the higher alcohols. The results in Figure 2 also indicate that although the changes in the production rates of alcohols and hydrocarbons have slowed down considerably during the initiation period, there still seems to be a slight time dependency of the activity during the period with variations of the $\mathrm{H}_{2} / \mathrm{CO}$ ratio $(48-93 \mathrm{~h}$ on stream). If the data points in Figure 2 are extrapolated by power-law or exponential functions, those functions indicate that the total production rate of $\mathrm{C}_{2}-\mathrm{C}_{4}$ alcohols may vary by up to $3 \%$ from the average value during the period of $48-93 \mathrm{~h}$ on stream. The total production rate of $\mathrm{C}_{1}-\mathrm{C}_{3}$ hydrocarbons may on the other hand vary by up to $6 \%$ compared to the average value during the period of $48-93 \mathrm{~h}$ on stream. The time dependency of the activity may thus for some components introduce a minor uncertainty $(3-6 \%)$ in the 


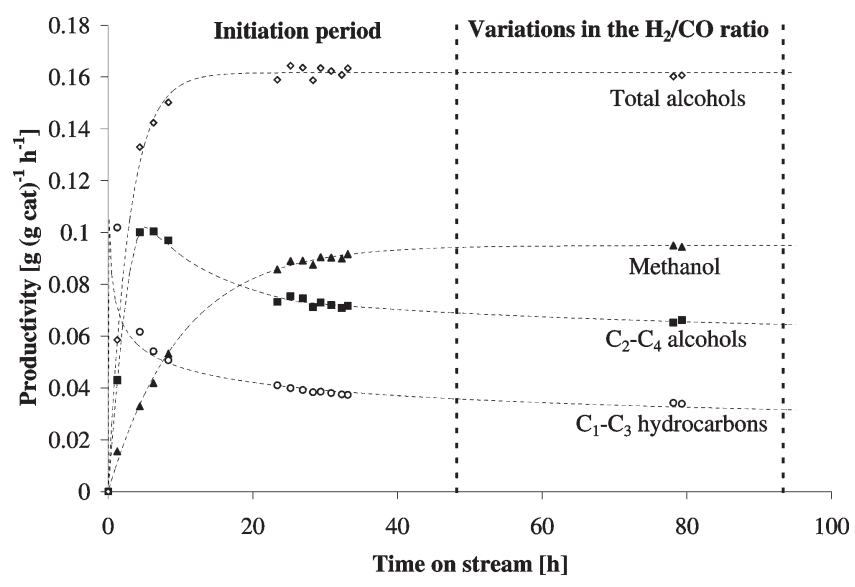

Figure 2. Production rates of various product classes as functions of the time on stream during the initiation and the variations in the $\mathrm{H}_{2} / \mathrm{CO}$ ratio. The productivities obtained at a molar $\mathrm{H}_{2} / \mathrm{CO}$ ratio of 0.96 during both of these periods are shown. The objective of this figure is to provide an indication of the degree of deactivation occurring during the variations in the $\mathrm{H}_{2} / \mathrm{CO}$ ratio. The experimental conditions are $P=100$ bar, $T=326^{\circ} \mathrm{C}$, gas hourly space velocity $(\mathrm{GHSV})=2600 \mathrm{~h}^{-1}$, 49.0 vol $\% \mathrm{H}_{2}$, and 51.0 vol $\% \mathrm{CO}$.

evaluation of the effect of the feed composition. Contrary to the case for higher alcohols and hydrocarbons, there are no indications of discernible variations in the methanol production rate during the variations in the $\mathrm{H}_{2} / \mathrm{CO}$ ratio.

Figure 3 shows the space-time yields of methanol, higher alcohols, and $\mathrm{C}_{1}-\mathrm{C}_{3}$ hydrocarbons as functions of the $\mathrm{H}_{2} / \mathrm{CO}$ ratio in the syngas feed. Figure 3 illustrates that the methanol production increases with an increasing hydrogen content in the feed, while the production of higher alcohol is optimal with an equimolar mixture of $\mathrm{CO}$ and $\mathrm{H}_{2}$. An equimolar mixture of $\mathrm{CO}$ and $\mathrm{H}_{2}$ also constitutes the stoichiometric feed for the synthesis of ethanol, the dominant higher alcohol, if it is assumed that all water coproduced in the ethanol synthesis is shifted into $\mathrm{CO}_{2}$ in the water gas shift reaction $(\mathrm{R} 2+\mathrm{R} 4)$. The production of hydrocarbons generally follows the production of higher alcohols, but at higher $\mathrm{H}_{2} / \mathrm{CO}$ ratios the production of hydrocarbons clearly approaches the production of higher alcohols. It is interesting to observe how the production rates of hydrocarbons and higher alcohols follow the same general tendency, while the production of methanol exhibits a completely different response to variations in the $\mathrm{H}_{2} / \mathrm{CO}$ ratio. It is also interesting to observe that the dominant effect of an increased feed hydrogen content is an increased hydrogenation of $\mathrm{CO}$ to form methanol. It thus appears that the catalyst favors $\mathrm{C}-\mathrm{O}$ bond retention. It might have been expected that an increased hydrogen content in the syngas feed especially would favor the hydrocarbon production, but at the presently employed conditions this is not the case.

The present observations agree quite well with previously reported results from the literature. Park et al. ${ }^{53}$ studied a $\mathrm{K}_{2} \mathrm{CO}_{3} / \mathrm{MoS}_{2}$ catalyst, and they also observed that the methanol production increased with an increasing feed hydrogen content, while the production of higher alcohols peaked around a molar $\mathrm{H}_{2} / \mathrm{CO}$ ratio of 1 . In a related investigation Youchang et al. ${ }^{54}$ also observed that an increase in the partial pressure of $\mathrm{H}_{2}$ at a fixed partial pressure of $\mathrm{CO}$ primarily enhanced the methanol selectivity. Furthermore, it is in the patent literature ${ }^{55-57}$ typically recommended that the sulfide catalyst is operated with a molar

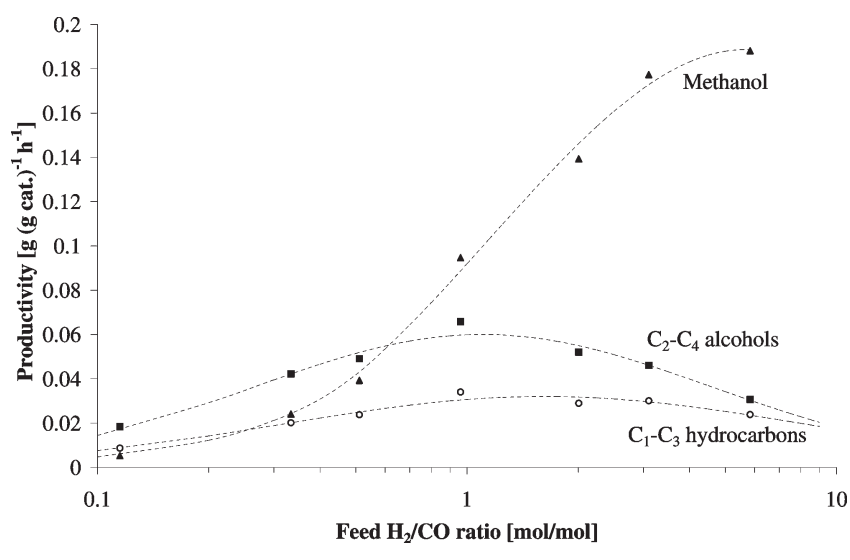

Figure 3. Production rates of methanol, higher alcohols, and hydrocarbons as functions of the $\mathrm{H}_{2} / \mathrm{CO}$ ratio in the syngas feed. The experimental conditions are $P=100 \mathrm{bar}, \mathrm{T}=326 \pm 1{ }^{\circ} \mathrm{C}$, GHSV $=$ $2600 \pm 25 \mathrm{~h}^{-1}$, and $+48 \mathrm{~h}$ on stream.

$\mathrm{H}_{2} / \mathrm{CO}$ ratio of around 1 in the feed. In an $\mathrm{H}_{2} \mathrm{~S}$-containing syngas we ${ }^{37}$ have previously determined experimental rate equations for the production of various alcohols and hydrocarbons from syngas, and on the basis of these rate equations one would expect that an increased $\mathrm{H}_{2} / \mathrm{CO}$ ratio especially would benefit the production of methane. For an $\mathrm{H}_{2} \mathrm{~S}$-containing feed Zhang et al. ${ }^{58}$ also observed that an increasing $\mathrm{H}_{2} / \mathrm{CO}$ ratio boosted the methane selectivity. The properties of the active phase, which stabilizes in the presence of $\mathrm{H}_{2} \mathrm{~S}$, may be so that hydrogenation without retention of the $\mathrm{C}-\mathrm{O}$ bond becomes a more favorable pathway.

Previous investigations suggest that chain growth for the sulfide catalyst occurs by addition of $\mathrm{CO}$ to an alkyl group to form an acyl species that can be hydrogenated into the corresponding alcohol. ${ }^{20,59}$ Alternatively, chain growth can take place by alcohol coupling reactions, which presumably occur via an aldol condensation pathway. ${ }^{42}$ For the higher alcohols it is most likely that it is the shared need for $\mathrm{CO}$ addition and hydrogenation reactions that creates an optimum in the productivity around a molar $\mathrm{H}_{2} / \mathrm{CO}$ ratio of 1 . It is also quite likely that an increased chance of hydrogenation of the alkyl intermediates into hydrocarbons is the reason why the production rate of hydrocarbons approaches the production rate of higher alcohols at higher $\mathrm{H}_{2}$ / CO ratios. Methanol may couple with ethanol or higher alcohols via an aldol condensation pathway, but it is quite likely that aldol condensation type couplings, which would involve aldehyde intermediates, become increasingly disfavored by an increase in the partial pressure of $\mathrm{H}_{2}$, which serves to displace the alcohol/ aldehyde equilibria toward the alcohols.

That the methanol production increases so significantly with an increasing $\mathrm{H}_{2} / \mathrm{CO}$ ratio has the implication that the overall alcohol selectivity also increases with an increasing $\mathrm{H}_{2} / \mathrm{CO}$ ratio in the syngas feed. This is illustrated in Figure 4, which shows the $\mathrm{CO}$ conversion, the $\mathrm{CO}_{2}$-free alcohol selectivity, and the $\mathrm{CO}_{2}$ selectivity as functions of the $\mathrm{H}_{2} / \mathrm{CO}$ ratio in the feed.

From Figure 4 it can be seen that the $\mathrm{CO}$ conversion increases markedly when the $\mathrm{H}_{2} / \mathrm{CO}$ ratio is increased. This is related to the strong increase in the methanol production rate, but it should also be kept in mind that the feed becomes increasingly $\mathrm{CO}$ deficient at the higher $\mathrm{H}_{2} / \mathrm{CO}$ ratios. Figure 4 also shows that the $\mathrm{CO}_{2}$ selectivity decreases with increasing hydrogen content in the feed. This is due to the fact that the water gas shift reaction (R4) 
is displaced toward the left with increasing hydrogen content in the gas, and due to the fact that the dominant reaction in a hydrogen-rich syngas becomes the direct hydrogenation of $\mathrm{CO}$ into methanol (R1), which does not result in a coproduction of $\mathrm{H}_{2} \mathrm{O} / \mathrm{CO}_{2}$.

The effects of the feed composition upon the $\mathrm{CO}$ conversion and the product selectivitites are also consistent with previous investigations. The results of Park et al. ${ }^{53}$ with a $\mathrm{K}_{2} \mathrm{CO}_{3} / \mathrm{MoS}_{2}$ catalyst also indicated a declining $\mathrm{CO}_{2}$ selectivity and a weakly increasing alcohol selectivity with an increasing $\mathrm{H}_{2} / \mathrm{CO}$ ratio, but Park et al. ${ }^{53}$ did not observe as strong an increase in the $\mathrm{CO}$ conversion with increasing $\mathrm{H}_{2} / \mathrm{CO}$ ratio as seen in the present experiments.

Table 3 illustrates the $\mathrm{CO}_{2}$-free product selectivities for selected $\mathrm{H}_{2} / \mathrm{CO}$ ratios. The results clearly show how methanol is the product that benefits from an increasing hydrogen content in the feed.

An evaluation of the equilibrium for the overall methanol synthesis reaction (R1) suggests that the beginning stagnation, which is seen in the methanol production at the highest $\mathrm{H}_{2} / \mathrm{CO}$ ratios in Figure 3, is due to the fact that the methanol synthesis here draws near its equilibrium boundary. With thermodynamic data from Barin ${ }^{60}$ one obtains a value of $K_{f, 599.15 \mathrm{~K}}=1.19 \times 10^{-4}$ $\mathrm{bar}^{-2}$ for the equilibrium constant at the reaction temperature of $326{ }^{\circ} \mathrm{C}$. Figure 5 shows the quantity $f_{\mathrm{MeOH}} /\left(K_{f} f_{\mathrm{H}_{2}}{ }^{2} f_{\mathrm{CO}}\right)$ at the reactor exit depicted as a function of the $\mathrm{H}_{2} / \mathrm{CO}$ ratio in the feed. As described in section 2 , the quantity $f_{\mathrm{MeOH}} /\left(K_{f} f_{\mathrm{H}_{2}}{ }^{2} f_{\mathrm{CO}}\right)$ is a measure of the degree of equilibration for the methanol synthesis reaction. The results in Figure 5 illustrate that the methanol synthesis at higher $\mathrm{H}_{2} / \mathrm{CO}$ ratios comes quite near the equilibrium

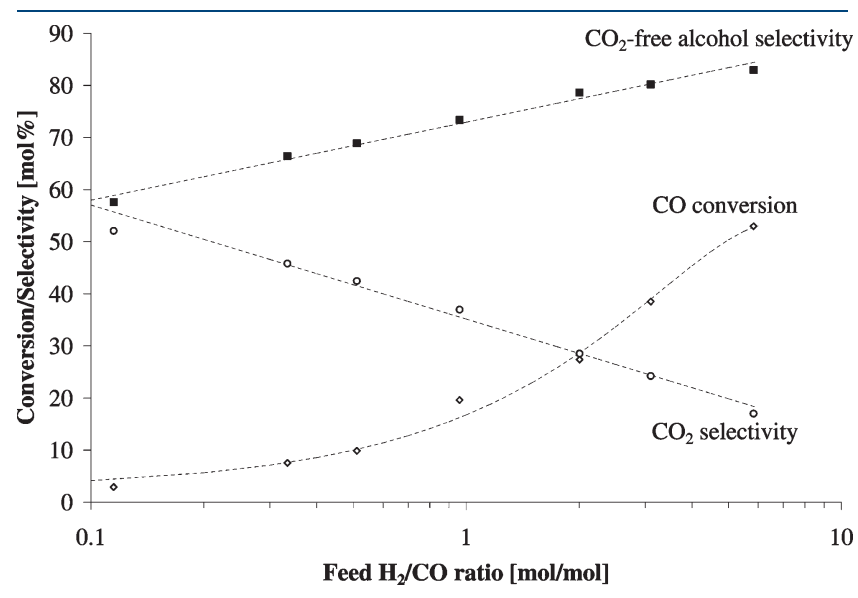

Figure 4. $\mathrm{CO}$ conversion, $\mathrm{CO}_{2}$ selectivity, and $\mathrm{CO}_{2}$-free alcohol selectivity as functions of the $\mathrm{H}_{2} / \mathrm{CO}$ ratio in the feed. The experimental conditions are given in the caption of Figure 3. boundary $\left(f_{\mathrm{MeOH}} /\left(K_{f} f_{\mathrm{H}_{2}}{ }^{2} f_{\mathrm{CO}}\right)=1\right)$. There is a significant scattering in the literature concerning the exact location of the methanol synthesis equilibrium, and it is possible to find equilibrium constants both above and below the value used in the present case. ${ }^{47,61-64}$ There is thus some uncertainty regarding the exact degree of equilibration for the methanol synthesis, but in light of the results in Figure 5 it does seem most likely that the beginning stagnation of the methanol synthesis rate at the highest $\mathrm{H}_{2} / \mathrm{CO}$ ratios in Figure 3 can be ascribed to the growing importance of the reverse reaction of $\mathrm{R} 1$. As described in section 2 , the fugacity coefficients have been determined by means of the SRK equation of state. Generally the compressibility factor and all the individual fugacity coefficients are within $5 \%$ of unity in all the experiments seen in Figure 5. The deviations from ideality are thus not large, but the accumulated deviation in products of fugacities can have a more significant impact on the equilibrium. For the experiments presented in Figure 5 one quite consistently has $\varphi_{\mathrm{MeOH}} /\left(\varphi_{\mathrm{H}_{2}}{ }^{2} \varphi_{\mathrm{CO}}\right)=0.890 \pm 0.006$, and at the high reaction pressure the deviations from ideality thus have a significant impact upon the location of the methanol synthesis equilibrium.

The equilibrium for the synthesis of the higher alcohols should generally be more favorable than the methanol synthesis equilibrium, ${ }^{65-67}$ and the synthesis of higher alcohols is therefore less likely to be equilibrium controlled. An evaluation of the equilibrium for the synthesis of higher alcohols would necessitate an evaluation of the water gas shift equilibrium. Such an evaluation has not been attempted, since the water content in the product stream has not been determined in the present investigations.

3.2. Role of $\mathrm{H}_{2} \mathrm{O} / \mathrm{CO}_{2}$ in Syngas. As illustrated in Table 1, the raw syngas from the gasifier may contain significant amounts of

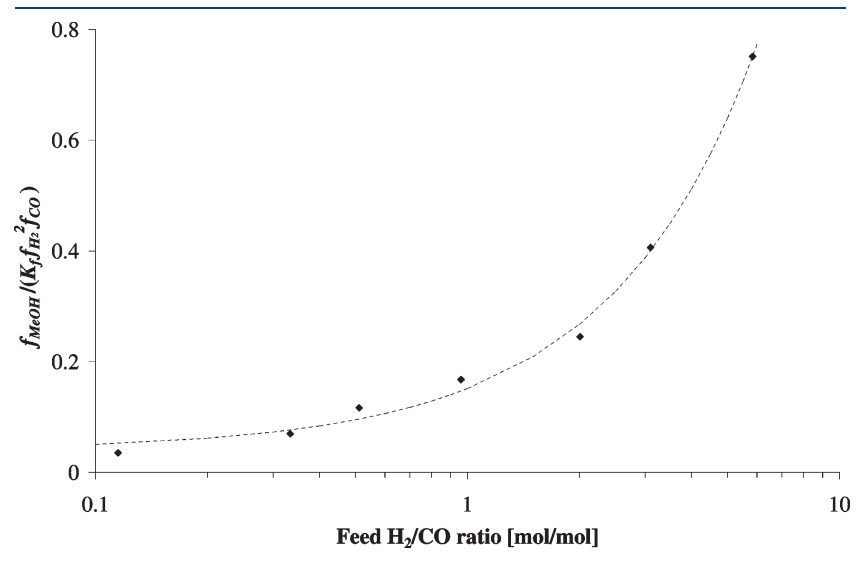

Figure 5. The quantity $f_{\mathrm{MeOH}} /\left(K_{f} f_{\mathrm{H}_{2}}{ }^{2} f_{\mathrm{CO}}\right)$ at the reactor exit depicted as a function of the $\mathrm{H}_{2} / \mathrm{CO}$ ratio in the feed. The experimental conditions are given in the caption of Figure 3.

Table 3. $\mathrm{CO}_{2}$-Free Product Selectivities for Various $\mathrm{H}_{2} / \mathrm{CO}$ Ratios in the Feed ${ }^{a}$

\begin{tabular}{|c|c|c|c|c|c|c|c|c|c|c|}
\hline \multirow[b]{2}{*}{$\mathrm{H}_{2} / \mathrm{CO}[\mathrm{mol} / \mathrm{mol}]$} & \multirow[b]{2}{*}{$\mathrm{CO}_{2}$-free $\mathrm{CO} \operatorname{conv}^{b}[\mathrm{~mol} \%]$} & \multicolumn{9}{|c|}{$\mathrm{CO}_{2}$-free, carbon-based selectivity $[\mathrm{mol} \%]$} \\
\hline & & $\mathrm{CH}_{4}$ & $\mathrm{C}_{2} \mathrm{H}_{4}$ & $\mathrm{C}_{2} \mathrm{H}_{6}$ & $\mathrm{C}_{3} \mathrm{H}_{8}$ & $\mathrm{MeOH}$ & $\mathrm{EtOH}$ & 1-PrOH & $1-\mathrm{BuOH}$ & iso- $\mathrm{BuOH}$ \\
\hline $0.11^{c}$ & 1.3 & 13.9 & 3.3 & 8.6 & 5.7 & 9.4 & 25.2 & 12.9 & 5.3 & 4.8 \\
\hline 0.96 & 13.2 & 19.5 & 1.1 & 3.1 & 2.4 & 35.6 & 17.6 & 12.5 & 2.1 & 5.7 \\
\hline 5.83 & 44.8 & 15.2 & 0.2 & 1.1 & 0.8 & 66.4 & 7.6 & 5.9 & 0.4 & 2.4 \\
\hline
\end{tabular}

${ }^{a}$ The experimental conditions are given in the caption of Figure $3 .{ }^{b} \mathrm{CO}$ conversion into products other than $\mathrm{CO}_{2}$. The total $\mathrm{CO}$ conversion can be seen in Figure 4. ${ }^{c}$ For the lowest $\mathrm{H}_{2} / \mathrm{CO}$ ratio it is an element of uncertainty that the GC spectra show signs of uncharacterized products-presumably compounds like higher alcohols/hydrocarbons, aldehydes, and esters. An ethyl acetate selectivity of $6.3 \mathrm{~mol} \%$ is observed. 


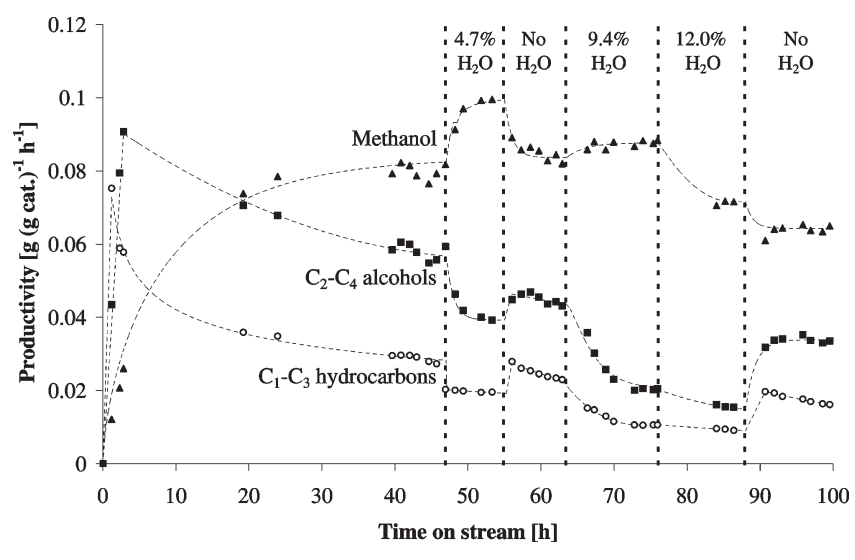

Figure 6. Production rates of methanol, $\mathrm{C}_{2}-\mathrm{C}_{4}$ alcohols, and $\mathrm{C}_{1}-\mathrm{C}_{3}$ hydrocarbons as functions of the time on stream with progressively increasing addition of $\mathrm{H}_{2} \mathrm{O}$ to the syngas feed. The water content in the syngas feed in mole percent is noted for each segment of the experiment. The experimental conditions are $P=100 \mathrm{bar}, T=326^{\circ} \mathrm{C}$, and GHSV $=$ $2765 \pm 80 \mathrm{~h}^{-1}$. Excluding $\mathrm{H}_{2} \mathrm{O}$, the feed contains 48.9 vol $\% \mathrm{H}_{2}, 51.1$ vol $\% \mathrm{CO}$, and no $\mathrm{H}_{2} \mathrm{~S}$.

water and $\mathrm{CO}_{2}$. It is therefore also important to clarify how these components may influence the properties of the sulfide catalyst and the synthesis process. Water and $\mathrm{CO}_{2}$ are as noted in the Introduction largely parallel products in the synthesis reactor, because the water gas shift reaction (R4) proceeds rapidly over the alcohol synthesis catalyst. Gang et al. ${ }^{25}$ also used a $\mathrm{K} / \mathrm{Co} /$ $\mathrm{MoS}_{2} / \mathrm{C}$ catalyst and observed that the water gas shift reaction generally is very close to equilibrium at typical alcohol synthesis conditions. Since the water gas shift reaction appears to be relatively rapid compared to the synthesis reactions, it is thus difficult to distinguish between the effects of $\mathrm{H}_{2} \mathrm{O}$ and $\mathrm{CO}_{2}$.

In these investigations water is co-fed along with the syngas sent to the reactor. Because the increased water content in the syngas feed could result in some degree of oxidation of the sulfide, and because such an oxidation could depend upon the sulfur level in the syngas, the investigations are conducted both with and without $222 \mathrm{ppmv}_{2} \mathrm{~S}$ in the syngas. These investigations are performed with an approximately equimolar mixture of $\mathrm{CO}$ and $\mathrm{H}_{2}$, since such a mixture as discussed in section 3.1 provides the optimal production of higher alcohols.

Figure 6 shows the production rates of alcohols and hydrocarbons as functions of the time on stream in a sulfur-free syngas with a progressively increasing addition of water to the syngas feed $\left(\mathrm{H}_{2} / \mathrm{CO}=0.96 \mathrm{~mol} / \mathrm{mol}\right)$. Figure 6 illustrates that the addition of water to the syngas feed causes a decline in the production of hydrocarbons and especially in the production of the higher alcohols. Figure 6 also illustrates that the methanol production benefits from a modest water content in the feed (4.7-9.4 mol \%). This may be related to a reduced consumption of methanol as a precursor for the production of higher alcohols. Another factor that may contribute to the increased methanol production is that the shift of the $\mathrm{H}_{2} \mathrm{O}$ co-fed with the syngas raises the hydrogen content in the gas from the original ratio of $\mathrm{H}_{2} / \mathrm{CO}=0.96 \mathrm{~mol} / \mathrm{mol}$. From section 3.1 it is known that the methanol production in the region of an equimolar $\mathrm{H}_{2} / \mathrm{CO}$ mixture benefits strongly from an increased hydrogen content in the syngas. From Figure 3 it can be seen that the production of higher alcohols has a relatively broad optimum in the region of a molar $\mathrm{H}_{2} / \mathrm{CO}$ ratio around 1 , but the increasing $\mathrm{H}_{2} / \mathrm{CO}$ ratio

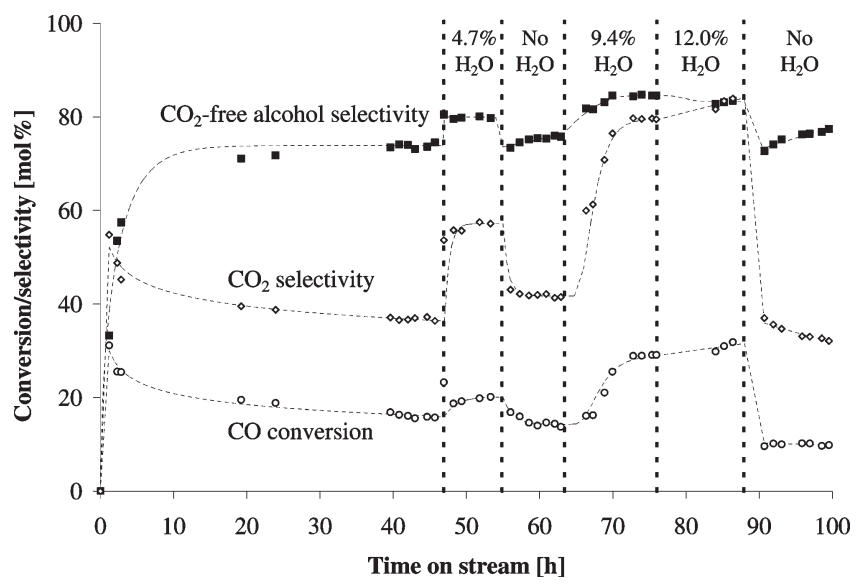

Figure 7. $\mathrm{CO}_{2}$-free alcohol selectivity, $\mathrm{CO}_{2}$ selectivity, and $\mathrm{CO}$ conversion as functions of the time on stream with progressively increasing addition of $\mathrm{H}_{2} \mathrm{O}$ to the $\mathrm{S}$-free syngas feed. The water content in the syngas feed in mole percent is noted for each segment of the experiment. The experimental conditions are given in the caption of Figure 6.

should also provide a minor contribution to the decline in the production of higher alcohols.

Additionally, the available evidence for $\mathrm{Cu}$-based methanol synthesis catalysts suggests that $\mathrm{CO}_{2}$ is the dominant source of carbon in methanol formed over such catalysts. ${ }^{68-71} \mathrm{~A}$ minor addition of $\mathrm{H}_{2} \mathrm{O}$ to $\mathrm{H}_{2} / \mathrm{CO}$ also enhances the methanol production over $\mathrm{Cu} / \mathrm{ZnO}$, in the same way as it is seen in Figure 6 for the sulfide catalyst. ${ }^{32}$ If the sulfide catalyst also has a favorable reaction pathway from $\mathrm{CO}_{2}$ to methanol, then the increased $\mathrm{CO}_{2}$ level arising from the shift of co-fed water could boost the methanol production rate.

It might look as though the catalyst at the highest water level $(12.0 \mathrm{~mol} \%)$ undergoes an irreversible change. In the final period with a water-free feed in Figure 6, the production rates of both methanol and $\mathrm{C}_{2}-\mathrm{C}_{4}$ alcohols have decreased by $24 \%$ compared to the activity before exposure to the higher water contents $(9.4-12.0 \mathrm{~mol} \%)$. With the declining production of hydrocarbons and higher alcohols and the increasing production of methanol, the overall alcohol selectivity actually increases with the addition of water to the syngas feed. This is illustrated in Figure 7, which shows the $\mathrm{CO}_{2}$-free alcohol selectivity, the $\mathrm{CO}_{2}$ selectivity, and the $\mathrm{CO}$ conversion during the experiment presented in Figure 6.

With thermodynamic data from Barin, ${ }^{60}$ the equilibrium constant for the water gas shift reaction at $326{ }^{\circ} \mathrm{C}$ is $K_{\mathrm{WGS}}=$ 27.9. At equilibrium the dominant part of the added water will therefore be shifted into $\mathrm{CO}_{2}$. Figure 7 illustrates that the $\mathrm{CO}$ conversion, despite the decreasing production of the synthesis products, increases significantly when water is added to the feed. The increase in the $\mathrm{CO}$ conversion corresponds relatively well to an essentially complete shift of the added water. From Figure 7 it can also be seen how the contribution from the shift reaction causes a marked increase in the $\mathrm{CO}_{2}$ selectivity. Even with the lowest feed water level (4.7 mol \%) the $\mathrm{CO}_{2}$ selectivity has increased to $57 \mathrm{~mol} \%$, and with $12.0 \mathrm{~mol} \%$ water in the syngas feed the $\mathrm{CO}_{2}$ selectivity has increased to $84 \mathrm{~mol} \%$.

Table 4 summarizes the individual product selectivities and the $\mathrm{CO}$ conversion into products other than $\mathrm{CO}_{2}$ for various $\mathrm{H}_{2} \mathrm{O}$ levels in the feed. The results in Table 4 emphasize that especially the production of higher species is hampered by water. 
Table 4. $\mathrm{CO}_{2}$-Free Product Selectivities for Various Water Levels in the $\mathrm{H}_{2} \mathrm{~S}$-Free Feed ${ }^{a}$

\begin{tabular}{|c|c|c|c|c|c|c|c|c|c|c|}
\hline \multirow[b]{2}{*}{$\mathrm{H}_{2} \mathrm{O}$ in feed $^{b}[\mathrm{vol} \%]$} & \multirow[b]{2}{*}{$\mathrm{CO}_{2}$-free $\mathrm{CO}$ conv $^{c}[\mathrm{~mol} \%]$} & \multicolumn{9}{|c|}{$\mathrm{CO}_{2}$-free, carbon-based selectivity $[\mathrm{mol} \%]$} \\
\hline & & $\mathrm{CH}_{4}$ & $\mathrm{C}_{2} \mathrm{H}_{4}$ & $\mathrm{C}_{2} \mathrm{H}_{6}$ & $\mathrm{C}_{3} \mathrm{H}_{8}$ & $\mathrm{MeOH}$ & $\mathrm{EtOH}$ & 1-PrOH & $1-\mathrm{BuOH}$ & iso- $\mathrm{BuOH}$ \\
\hline 0 & 10.3 & 20.0 & 1.1 & 3.0 & 2.2 & 34.7 & 19.3 & 11.5 & 2.6 & 5.0 \\
\hline 4.7 & 7.8 & 16.9 & 0.7 & 1.3 & 1.1 & 50.1 & 15.6 & 8.8 & 1.2 & 4.1 \\
\hline 9.4 & 5.9 & 13.3 & 0.6 & 0.7 & 0.7 & 62.8 & 12.6 & 6.0 & 0.7 & 2.4 \\
\hline 12.0 & 4.9 & 13.5 & 1.2 & 0.9 & 0.9 & 63.2 & 12.0 & 5.6 & 0.8 & 1.9 \\
\hline
\end{tabular}

${ }^{a}$ The experimental conditions are given in the caption of Figure $6 .{ }^{b} \mathrm{H}_{2} \mathrm{O}$ fraction in the feed. The value for $\mathrm{H}_{2} \mathrm{O}$-free syngas corresponds to the value after $40-47 \mathrm{~h}$ on stream. ${ }^{c} \mathrm{CO}$ conversion into products other than $\mathrm{CO}_{2}$. The total $\mathrm{CO}$ conversion can be seen in Figure 7.

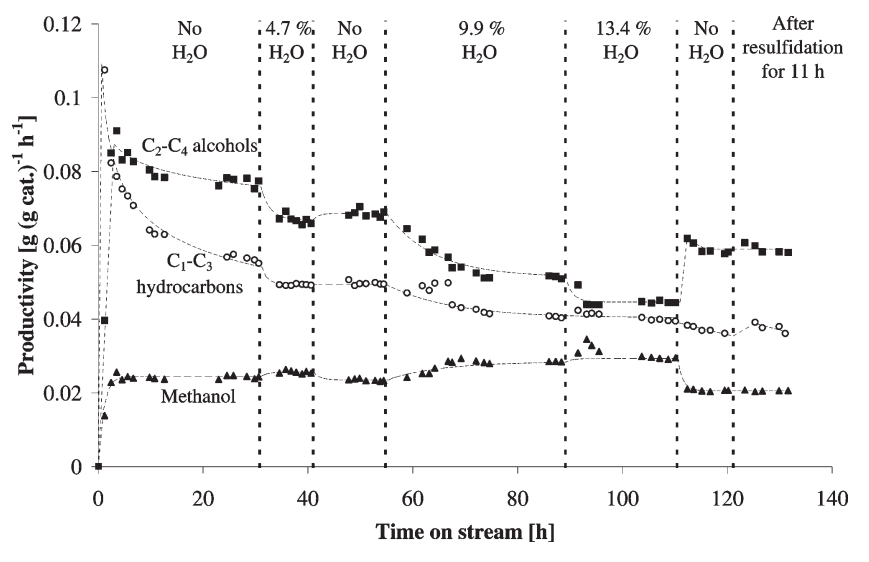

Figure 8. Production rates of methanol, $\mathrm{C}_{2}-\mathrm{C}_{4}$ alcohols, and $\mathrm{C}_{1}-\mathrm{C}_{3}$ hydrocarbons as functions of the time on stream with progressively increasing addition of $\mathrm{H}_{2} \mathrm{O}$ to the $\mathrm{H}_{2} \mathrm{~S}$-containing syngas feed. The water content in the syngas feed in mole percent is noted for each segment of the experiment. The experimental conditions are $P=100$ bar, $T=326{ }^{\circ} \mathrm{C}$, and GHSV $=2795 \pm 90 \mathrm{~h}^{-1}$. Excluding $\mathrm{H}_{2} \mathrm{O}$, the feed contains $49.1 \mathrm{vol} \% \mathrm{H}_{2}, 50.9 \mathrm{vol} \% \mathrm{CO}$, and $222 \mathrm{ppmv} \mathrm{H}_{2} \mathrm{~S}$. Before the last stage of the experiment, the catalyst is resulfided for $11 \mathrm{~h}$ at $325{ }^{\circ} \mathrm{C}$ and atmospheric pressure in an $80 \mathrm{NmL} / \mathrm{min}$ flow of $2 \mathrm{~mol} \% \mathrm{H}_{2} \mathrm{~S}$ in $\mathrm{H}_{2}$.

With 222 ppmv $\mathrm{H}_{2} \mathrm{~S}$ in the syngas the qualitative effects of the water addition are largely similar to the effects in an $\mathrm{H}_{2} \mathrm{~S}$-free syngas. As the presence of $\mathrm{H}_{2} \mathrm{~S}$ boosts the production rates of hydrocarbons and higher alcohols and lowers the production rate of methanol, the starting point is however quite different in the $\mathrm{H}_{2} \mathrm{~S}$-containing syngas. Figure 8 illustrates the production rates of alcohols and hydrocarbons as functions of the time on stream with a progressively increasing addition of water to the $\mathrm{H}_{2} \mathrm{~S}$ containing syngas feed $\left(\mathrm{H}_{2} / \mathrm{CO}=0.96 \mathrm{~mol} / \mathrm{mol}\right)$.

Figure 8 again illustrates how the how the production rates of hydrocarbons and higher alcohols are progressively lowered by the increasing co-feeding of water. The exposure to $4.7 \mathrm{~mol} \%$ $\mathrm{H}_{2} \mathrm{O}$ appears to cause a permanent loss of activity for the production of hydrocarbons and higher alcohols. The exposure of the catalyst to 9.9 and $13.4 \mathrm{~mol} \% \mathrm{H}_{2} \mathrm{O}$ lowers the production of hydrocarbons/higher alcohols further, but the removal of water from the feed restores part of the activity. With $222 \mathrm{ppmv}$ $\mathrm{H}_{2} \mathrm{~S}$ in the syngas the methanol production rate benefits from the co-feeding of $\mathrm{H}_{2} \mathrm{O}$ in the entire $0-13.4 \mathrm{~mol} \%$ range. This is contrary to the situation with a sulfur-free syngas, where exposure to $12.0 \mathrm{~mol} \% \mathrm{H}_{2} \mathrm{O}$ causes a permanent loss of methanol synthesis activity. This difference may be related to the fact that the methanol production rate is significantly lower in the $\mathrm{H}_{2} \mathrm{~S}$-containing syngas. Figure 8 also shows that 11 h of resulfidation at $325^{\circ} \mathrm{C}$

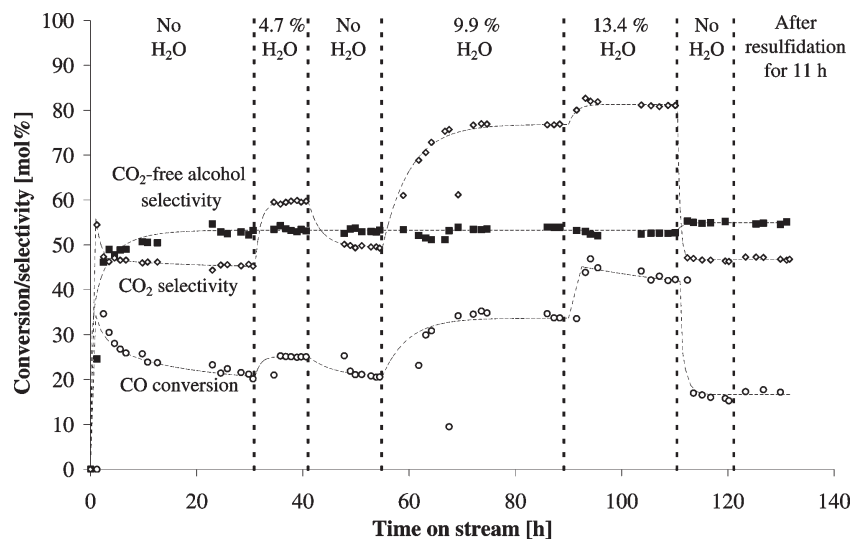

Figure 9. $\mathrm{CO}_{2}$-free alcohol selectivity, $\mathrm{CO}_{2}$ selectivity, and $\mathrm{CO}$ conversion as functions of the time on stream with progressively increasing addition of $\mathrm{H}_{2} \mathrm{O}$ to the $\mathrm{H}_{2} \mathrm{~S}$-containing syngas feed. The water content in the syngas feed in mole percent is noted for each segment of the experiment. The experimental conditions are given in the caption of Figure 8.

and atmospheric pressure does not alter the properties of the catalyst, which has been exposed to syngas containing 0-13.4 mol \% $\mathrm{H}_{2} \mathrm{O}$. The fact that a resulfidation is without influence on the catalytic properties is an argument against a partial oxidation of the sulfide as the reason for the loss of activity. If a partial oxidation of the catalyst occurs, it certainly leaves the catalyst in a state that is not resulfided with the normal sulfiding procedure. With 222 ppmv $\mathrm{H}_{2} \mathrm{~S}$ in the syngas, where higher alcohols and hydrocarbons are the dominant products, the co-feeding of water along with the syngas is virtually without an effect upon the alcohol selectivity. This is illustrated in Figure 9, which shows the $\mathrm{CO}_{2}$-free alcohol selectivity, the $\mathrm{CO}_{2}$ selectivity, and the $\mathrm{CO}$ conversion during the experiment with $\mathrm{H}_{2} \mathrm{O}$ co-feeding in an $\mathrm{H}_{2} \mathrm{~S}$-containing atmosphere. Figure 9 illustrates how the alcohol selectivity is unaltered through the $\mathrm{H}_{2} \mathrm{O}$ co-feeding experiment, although the selectivity increases slightly when water is finally removed from the feed stream. Furthermore, Figure 9 shows that the $\mathrm{CO}$ conversion also increases in an $\mathrm{H}_{2} \mathrm{~S}$-containing syngas when $\mathrm{H}_{2} \mathrm{O}$ is added to the feed. The increase in the $\mathrm{CO}$ conversion corresponds reasonably well to an essentially full shift of the cofed water, and Figure 9 also shows how the $\mathrm{CO}_{2}$ selectivity increases substantially when water is added to the syngas feed. For the part of the experiment with $13.4 \mathrm{vol} \% \mathrm{H}_{2} \mathrm{O}$ in the feed, the increase in the $\mathrm{CO}$ conversion is actually observed to be slightly higher than would be expected-even for a full shift of the co-fed water. This must be ascribed to experimental uncertainty, which is difficult to avoid when such a high fraction of a normally liquid component is co-fed along with the gaseous feed. 
Table 5. $\mathrm{CO}_{2}$-Free Product Selectivities for Various Water Levels with $222 \mathrm{ppmv}_{2} \mathrm{~S}$ in the Feed ${ }^{a}$

\begin{tabular}{|c|c|c|c|c|c|c|c|c|c|c|}
\hline \multirow[b]{2}{*}{$\mathrm{H}_{2} \mathrm{O}$ in $\mathrm{feed}^{b}[\mathrm{vol} \%]$} & \multirow[b]{2}{*}{$\mathrm{CO}_{2}$-free $\mathrm{CO}$ conv $^{c}[\mathrm{~mol} \%]$} & \multicolumn{9}{|c|}{$\mathrm{CO}_{2}$-free, carbon-based selectivity $[\mathrm{mol} \%]$} \\
\hline & & $\mathrm{CH}_{4}$ & $\mathrm{C}_{2} \mathrm{H}_{4}$ & $\mathrm{C}_{2} \mathrm{H}_{6}$ & $\mathrm{C}_{3} \mathrm{H}_{8}$ & $\mathrm{MeOH}$ & $\mathrm{EtOH}$ & 1-PrOH & $1-\mathrm{BuOH}$ & iso- $\mathrm{BuOH}$ \\
\hline 0 & 12.5 & 28.3 & 1.1 & 9.3 & 4.4 & 9.3 & 25.2 & 12.0 & 3.2 & 3.5 \\
\hline 4.7 & 9.2 & 29.6 & 1.0 & 8.6 & 4.2 & 11.0 & 25.5 & 10.6 & 3.0 & 3.1 \\
\hline 9.9 & 8.3 & 31.0 & 0.9 & 7.1 & 4.0 & 14.8 & 24.8 & 9.3 & 2.3 & 2.7 \\
\hline 13.4 & 7.8 & 33.3 & 0.8 & 6.9 & 3.8 & 16.4 & 23.9 & 8.6 & 2.2 & 1.6 \\
\hline
\end{tabular}

${ }^{a}$ The experimental conditions are given in the caption of Figure $8 .{ }^{b} \mathrm{H}_{2} \mathrm{O}$ fraction in the feed. The value for $\mathrm{H}_{2} \mathrm{O}$-free syngas corresponds to the value after $23-31 \mathrm{~h}$ on stream. ${ }^{c} \mathrm{CO}$ conversion into products other than $\mathrm{CO}_{2}$. The total $\mathrm{CO}$ conversion can be seen in Figure 9.

Table 6. Effect of Feed $\mathrm{CO}_{2}$ Level on the Production Rates of Various Reaction Products ${ }^{32,73 a}$

\begin{tabular}{|c|c|c|c|c|c|c|c|c|}
\hline \multirow[b]{2}{*}{$\mathrm{CO}_{2}$ fraction in feed [vol \%] } & \multirow[b]{2}{*}{$\mathrm{CO}$ conv $[\mathrm{mol} \%]$} & \multirow[b]{2}{*}{ GHSV $\left[h^{-1}\right]$} & \multicolumn{6}{|c|}{ product space time yield $[\mathrm{g} /(\mathrm{kg}$ of catalyst $\cdot \mathrm{h})]$} \\
\hline & & & $\mathrm{MeOH}$ & $\mathrm{EtOH}$ & 1-PrOH & $\mathrm{CH}_{4}$ & $\mathrm{C}_{2} \mathrm{H}_{6}$ & $\mathrm{H}_{2} \mathrm{O}$ \\
\hline 0.0 & 24.5 & 2000 & 166.9 & 70.4 & 22.9 & 64.2 & 19.9 & 7.1 \\
\hline 6.7 & 22.5 & 1600 & 145.7 & 40.6 & 10.4 & 58.8 & 7.1 & 12.8 \\
\hline 15.0 & 18.9 & 1900 & 144.0 & 33.5 & 7.2 & 42.1 & 0.0 & 17.1 \\
\hline 30.3 & 12.0 & 1800 & 81.5 & 25.1 & 5.9 & 25.1 & 4.3 & 21.8 \\
\hline
\end{tabular}

Table 7. Effect of Feed $\mathrm{CO}_{2}$ Level on the Selectivities of Various Products ${ }^{32,73 a}$

\begin{tabular}{|c|c|c|c|c|c|c|c|}
\hline \multirow[b]{2}{*}{$\mathrm{CO}_{2}$ fraction in feed [vol \%] } & \multirow[b]{2}{*}{$\mathrm{CO}_{2}$-free $\mathrm{CO}$ conv $[\mathrm{mol} \%]$} & \multirow[b]{2}{*}{ GHSV $\left[\mathrm{h}^{-1}\right]$} & \multicolumn{5}{|c|}{$\mathrm{CO}_{2}$-free, carbon-based selectivity $[\mathrm{mol} \%]$} \\
\hline & & & $\mathrm{MeOH}$ & $\mathrm{EtOH}$ & 1-PrOH & $\mathrm{CH}_{4}$ & $\mathrm{C}_{2} \mathrm{H}_{6}$ \\
\hline 0.0 & 12.2 & 2000 & 35.4 & 20.7 & 7.8 & 27.2 & 9.0 \\
\hline 6.7 & 13.2 & 1600 & 41.4 & 16.1 & 4.7 & 33.4 & 4.3 \\
\hline 15.0 & 10.1 & 1900 & 50.3 & 16.3 & 4.0 & 29.4 & 0.0 \\
\hline 30.3 & 6.2 & 1800 & 44.0 & 18.9 & 5.1 & 27.1 & 4.9 \\
\hline
\end{tabular}

Table 5 summarizes the individual product selectivities and the conversion into products other than $\mathrm{CO}_{2}$ for various $\mathrm{H}_{2} \mathrm{O}$ levels in the feed. The results in Table 5 also illustrate how water lowers the synthesis activity and shifts the product toward the $C_{1}$ species methane and methanol.

Due to the parallel nature of water and $\mathrm{CO}_{2}$ in the synthesis reactor, it is highly relevant to compare the effects of water in the feed to the effects of $\mathrm{CO}_{2}$ in the feed. The presence of $\mathrm{CO}_{2}$ in the syngas feed is generally reported to have a detrimental effect upon the alcohol synthesis over $\mathrm{MoS}_{2}$-based catalysts. In the patent literature $^{21,72}$ it is recommended that the partial pressure of carbon dioxide is kept below 1 bar at the reactor entry. Herman $^{32}$ has reported results from experiments made by the British Coal Research Establishment, ${ }^{73}$ where the $\mathrm{CO}_{2}$ level in the syngas passed over a $\mathrm{K}_{2} \mathrm{CO}_{3} / \mathrm{MoS}_{2} / \mathrm{C}$ catalyst has been varied. These results are summarized in Tables 6 and 7, which show the production rates and carbon-based selectivities for various reaction products with different $\mathrm{CO}_{2}$ levels in the syngas feed. ${ }^{32,73}$ The results in Tables 6 and 7 illustrate that in terms of the alcohol/hydrocarbon synthesis there are strong similarities between the reported effect of $\mathrm{CO}_{2}$ and the presently observed effect of $\mathrm{H}_{2} \mathrm{O}$. The presence of $\mathrm{CO}_{2}$ lowers the production rates for alcohols and hydrocarbons and especially the production of the higher species. This shifts the selectivity toward the $C_{1}$ products methane and methanol. It is the same effect that is observed with $\mathrm{H}_{2} \mathrm{O}$ in the syngas feed. The methanol production is only modestly affected by $\mathrm{CO}_{2}$ levels in the $0-15 \mathrm{~mol} \%$ range, but at a high feed $\mathrm{CO}_{2}$ level of $30.3 \mathrm{~mol} \%$ the production of methanol is significantly diminished. This behavior bears some qualitative resemblance to the behavior seen in Figure 6, where the methanol production is enhanced at lower $\mathrm{H}_{2} \mathrm{O}$ levels in the feed (0-9.4 mol \%), but significantly diminished at a higher water level $(12.0 \mathrm{~mol} \%)$. Since $\mathrm{CO}_{2}$ is the product favored by the water gas shift equilibrium, the presence of $\mathrm{CO}_{2}$ in the feed does not give rise to an increased $\mathrm{CO}$ conversion due to the shift reaction, as seen when $\mathrm{H}_{2} \mathrm{O}$ is added to the feed. When $\mathrm{CO}_{2}$ is added to the feed, there is thus only a lowering of the conversion due to the poisoning of the synthesis reactions. Also, Gang et al. ${ }^{25}$ have reported that the selectivity to higher alcohols is lowered when $\mathrm{CO}_{2}$ is added to the feed.

Figures 6-9 indicate that the deactivation of the synthesis reactions, which is caused by water, is partially irreversible. Unfortunately, no spectroscopic or compositional analyses were obtained for the present catalysts exposed to elevated water concentrations. It is therefore not possible to establish if changes in the structure and composition of the catalytically active phase are part of the reason for the reduced synthesis activity seen in the presence of elevated water levels. The partly irreversible nature of the deactivation does, however, indicate that such changes in the active phase do occur. One type of alteration in the active phase 
that might be envisioned is a partial oxidation of the sulfide. $\mathrm{MoS}_{2}$ has a sandwich structure with a layer of Mo atoms between two sheets of sulfur atoms. $\mathrm{MoS}_{2}$ can potentially be terminated by two low Miller index planes, namely the $\mathrm{Mo}(10 \overline{1} 0)$ edge and the

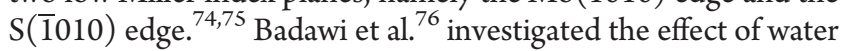
upon the structure of $\mathrm{MoS}_{2}$ by means of density functional theory, and these authors ${ }^{76}$ observed that especially the $S$-edge of the sulfide is susceptible to replacement of sulfur with oxygen, if the $\mathrm{H}_{2} \mathrm{O} / \mathrm{H}_{2} \mathrm{~S}$ ratio is of sufficient magnitude. Furthermore, the investigations of Karolewski and Cavell ${ }^{77}$ on $\mathrm{Cs} / \mathrm{MoS}_{2}(0001)$ suggested that the alkali metal promoted sulfide could be more susceptible to oxidation by $\mathrm{H}_{2} \mathrm{O}$ than the bare sulfide. Laurent and Delmon ${ }^{78}$ studied the effect of water upon an Ni/MoS $2 / \gamma$ $\mathrm{Al}_{2} \mathrm{O}_{3}$ catalyst employed for hydrodeoxygenation reactions. These authors ${ }^{78}$ observed no signs of oxidation of the $\mathrm{MoS}_{2}$ phase, but they ${ }^{78}$ did observe a partial oxidation of nickel. As one possible option, Laurent and Delmon ${ }^{78}$ suggested that the oxidation of $\mathrm{Ni}$ could be related to the formation of an inactive layer of nickel sulfate species that blocked the sulfide and lowered the catalytic activity.

Without $\mathrm{H}_{2} \mathrm{~S}$ in the syngas it appears to be especially the highest employed water level $(12.0 \mathrm{~mol} \%)$ that causes a rather general, permanent deactivation with only minor changes in selectivity and alcohol distribution. Judging from the relatively general effect, it might be simple sintering that lowers the activity. It possible that the elevated water levels could accelerate the sintering of the system. With 222 ppmv $\mathrm{H}_{2} \mathrm{~S}$ in the syngas the permanent deactivation caused by the elevated water levels is also rather general in its effect, and this could perhaps also point to a general sintering. In the presence of $\mathrm{H}_{2} \mathrm{~S}$ the deactivation of the higher alcohol production is slightly more significant than the deactivation of the methanol synthesis. This could be related to an effect upon the cobalt chain-growth promoter, but since a resulfidation of the catalyst is without any significant effect, the deactivation is not necessarily related to a partial oxidation.

While the permanent deactivation, which remains after $\mathrm{H}_{2} \mathrm{O}$ has been removed from the feed, is a relatively general effect, the presence of elevated $\mathrm{H}_{2} \mathrm{O} / \mathrm{CO}_{2}$ levels in the feed primarily causes a diminished production of the higher species. There are several factors that should be contributing to this negative influence of $\mathrm{H}_{2} \mathrm{O} / \mathrm{CO}_{2}$ upon the chain growth. It is described in section 3.1 how one of the available routes to chain growth is the coupling of alcohols, which appears to occur via an aldol condensation pathway. It is well-established that base catalyzed aldol condensation reactions are poisoned by water or $\mathrm{CO}_{2},{ }^{79-81}$ and this poisoning effect could very well be a significant part of the explanation for the declining production of higher alcohols. For the other possible route to chain growth, namely the $\mathrm{CO}$ addition reactions, the presence of cobalt appears to be very important. Calafat and Laine ${ }^{82,83}$ have observed that addition of Co to carbon-supported $\mathrm{MoS}_{2}$ greatly benefits the addition of $\mathrm{CO}$ to methanol to form $\mathrm{C}_{2}$ oxygenates. If $\mathrm{Co}$ due to the increased water levels becomes partly oxidized, in the same way as $\mathrm{H}_{2} \mathrm{O}$ may oxidize $\mathrm{Ni}$ added to $\mathrm{MoS}_{2}$, then this oxidation could also mean an alteration of the activity for the $\mathrm{CO}$ addition reactions that contribute to the chain growth. Additionally, Chen et al. ${ }^{84}$ used density functional theory to study the formation of ethanol by addition of $\mathrm{CO}$ to methanol over $\mathrm{MoS}_{2}$, and their ${ }^{84}$ investigations might suggest that the initial step is a $\mathrm{C}-\mathrm{O}$ bond breakage in methanol through an elementary reaction of the type given in eq R5:

$$
\mathrm{CH}_{3} \mathrm{OH}+\mathrm{H} \rightleftharpoons \mathrm{CH}_{3}+\mathrm{H}_{2} \mathrm{O}
$$

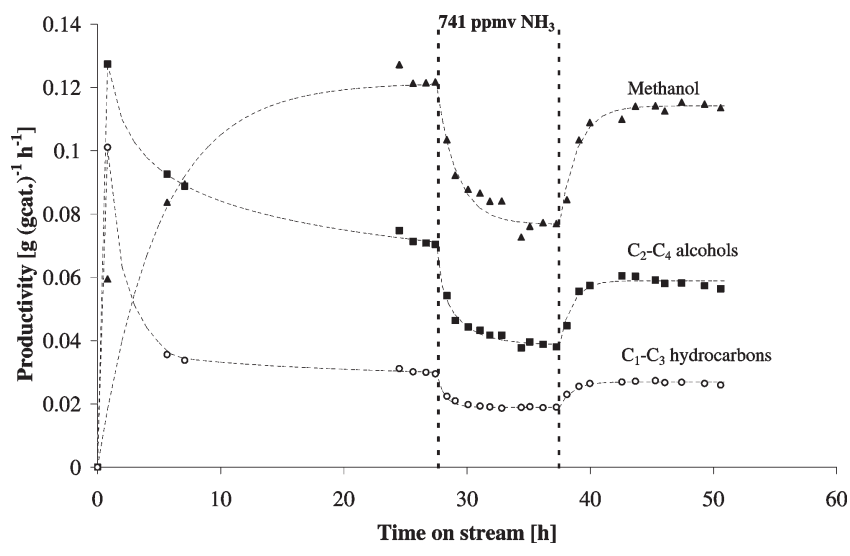

Figure 10. Production rates of methanol, $C_{2}-C_{4}$ alcohols, and $C_{1}-C_{3}$ hydrocarbons as functions of the time on stream in an $\mathrm{H}_{2} \mathrm{~S}$-free syngas. After $27.7 \mathrm{~h}$ on stream $741 \mathrm{ppmv} \mathrm{NH}_{3}$ is added to the syngas feed, and the $\mathrm{NH}_{3}$ addition is maintained for $10 \mathrm{~h}$. The experimental conditions are $T=326^{\circ} \mathrm{C}, P=100 \mathrm{bar}$, and GHSV $=5525 \mathrm{~h}^{-1}$. Feed: $49 \pm 1$ vol $\%$ $\mathrm{H}_{2}$ and $51 \pm 1$ vol \% CO.

It is quite likely that the rate of such an elementary reaction would be adversely affected by an elevated presence of water on the catalyst surface. There are thus several kinetic and structural effects that could hamper the chain growth in the presence of $\mathrm{H}_{2} \mathrm{O} / \mathrm{CO}_{2}$.

Gang et al. ${ }^{25}$ have previously also mentioned the adverse effect of elevated water levels upon the equilibrium for the synthesis of higher species ( $\mathrm{R} 2$ and $\mathrm{R} 3$ ) as a possible reason for the declining production of higher alcohols with $\mathrm{H}_{2} \mathrm{O} / \mathrm{CO}_{2}$ in the feed.

In light of the preceding discussion it seems fairly reasonable that the synthesis activity, and especially the production of higher species, is adversely effected by the presence of $\mathrm{H}_{2} \mathrm{O} / \mathrm{CO}_{2}$ in the syngas feed.

When larger amounts of water are added to the syngas, it is also likely that the synthesis reactions in general are hampered by a significant consumption of $\mathrm{CO}$ in the water gas shift reaction, which removes available carbon monoxide from the surface of the catalyst. As illustrated by the $\mathrm{CO}_{2}$ selectivity in Figures 7 and 9, the water gas shift reaction becomes very dominant at higher water levels.

3.3. Role of $\mathrm{NH}_{3}$. As mentioned in the Introduction, ammonia is a potential impurity in syngas derived from gasification. Presently the impact that $730-745$ ppmv $\mathrm{NH}_{3}$ has upon the catalytic activity is evaluated. The typical ammonia level in syngas has been discussed in the Introduction, and on the basis of that discussion the presently employed $\mathrm{NH}_{3}$ level should correspond to an intermediate level for wood gasification, while the investigated $\mathrm{NH}_{3}$ level is slightly low compared to the concentration typically found in syngas derived from coal gasification.

The $\mathrm{K}_{2} \mathrm{CO}_{3} / \mathrm{Co} / \mathrm{MoS}_{2} / \mathrm{C}$ catalyst is allowed to stabilize for $27.7 \mathrm{~h}$ in a sulfur-free syngas, and ammonia is then added to the syngas to a content of 741 ppmv. Figure 10 illustrates the developments in the production rates of alcohols and hydrocarbons as functions of the time on stream for this experiment. Figure 10 illustrates that the addition of $741 \mathrm{ppmv} \mathrm{NH}_{3}$ to the feed severely poisons the catalyst. This $\mathrm{NH}_{3}$ level causes a $41 \%$ reduction in activity (the total alcohol production rate drops from 0.194 to $0.116 \mathrm{~g}$ ( $\mathrm{g}$ of catalyst $)^{-1} \mathrm{~h}^{-1}$ ). The relative loss of activity is the same for both methanol and higher alcohols. Figure 10 also shows that the poisoning is largely reversible. Once the ammonia is 


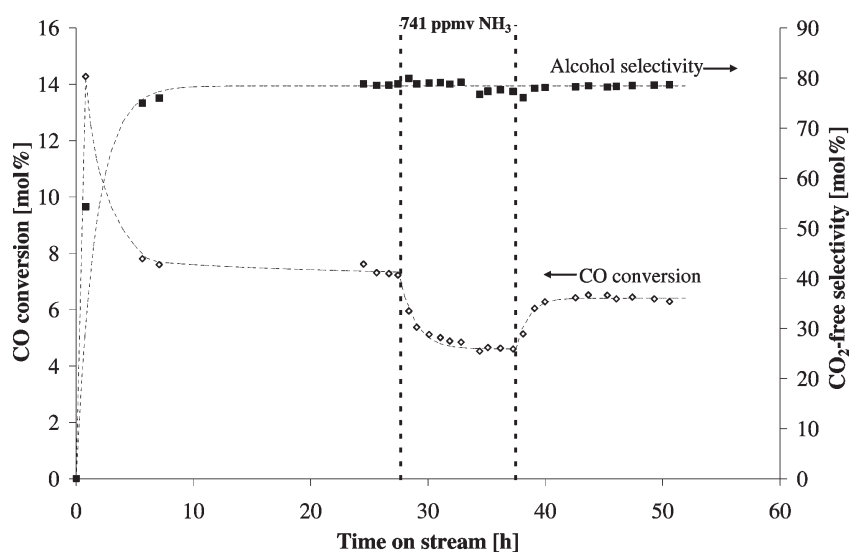

Figure 11. $\mathrm{CO}$ conversion and $\mathrm{CO}_{2}$-free alcohol selectivity as functions of the time on stream in a sulfur-free syngas. After $27.7 \mathrm{~h}$ on stream 741 ppmv $\mathrm{NH}_{3}$ is added to the syngas feed, and the $\mathrm{NH}_{3}$ addition is maintained for $10 \mathrm{~h}$. The experimental conditions are given in the caption of Figure 10.

removed from the feed, the catalyst regains a significant portion of its original activity. The original production rates for especially the higher alcohols are not completely restored, but judging from the trend in the activity prior to the ammonia addition there might also be an inherent decline in the production of higher alcohols (see Figure 2), and the reduced alcohol production after the exposure to ammonia may therefore be not only an effect of $\mathrm{NH}_{3}$, but also an effect of time. Although it is somewhat difficult to see with the scaling of Figure 10, the relative decline in the production rate upon exposure to ammonia is the same for both alcohols and hydrocarbons. The selectivity is thus essentially unaffected by the presence of ammonia. This is illustrated in Figure 11, which shows the developments in the $\mathrm{CO}$ conversion and the $\mathrm{CO}_{2}$-free alcohol selectivity as functions of the time on stream. Figure 11 illustrates the deactivation of the catalyst when ammonia is present in the syngas, but in addition to this Figure 11 shows how the alcohol selectivity is unaffected by the presence of ammonia.

A reversible poisoning is also the result when the freshly sulfided catalyst prior to the catalytic test at $325^{\circ} \mathrm{C}$ and 1 atm is exposed to an $80 \mathrm{NmL} / \mathrm{min}$ flow of $6115 \mathrm{ppmv} \mathrm{NH}_{3}$ in $\mathrm{H}_{2}$ for 90 $\mathrm{min}$. Figure 12 shows a comparison between the alcohol production rates for the ammonia treated catalyst and for an untreated sulfide.

Figure 12 illustrates that the catalyst which has been pretreated with $\mathrm{NH}_{3}$ in $\mathrm{H}_{2}$ initially suffers from a reduced activity compared to the catalyst without ammonia treatment, but the $\mathrm{NH}_{3}$-treated catalyst soon reaches the level of the untreated catalyst, and from around $5 \mathrm{~h}$ on stream the properties of the two catalysts are virtually indistinguishable. This result again points to an essentially reversible deactivation caused by ammonia.

The effect of ammonia has also been evaluated with $144 \mathrm{ppmv}$ $\mathrm{H}_{2} \mathrm{~S}$ in the syngas. Figure 13 shows the production rates of alcohols and hydrocarbons as functions of the time on stream during an ammonia-poisoning experiment in the presence of $\mathrm{H}_{2} \mathrm{~S}$. Figure 13 illustrates that ammonia also in the presence of $\mathrm{H}_{2} \mathrm{~S}$ causes a pronounced deactivation of the catalyst. The total alcohol production decreases by $19 \%$ (the total alcohol production rate drops from 0.135 to $0.110 \mathrm{~g}$ (g of catalyst $)^{-1} \mathrm{~h}^{-1}$ ), and the production of ethanol and higher alcohols decreases by $23 \%$. The relative decline in the hydrocarbon production rate is $15 \%$, which

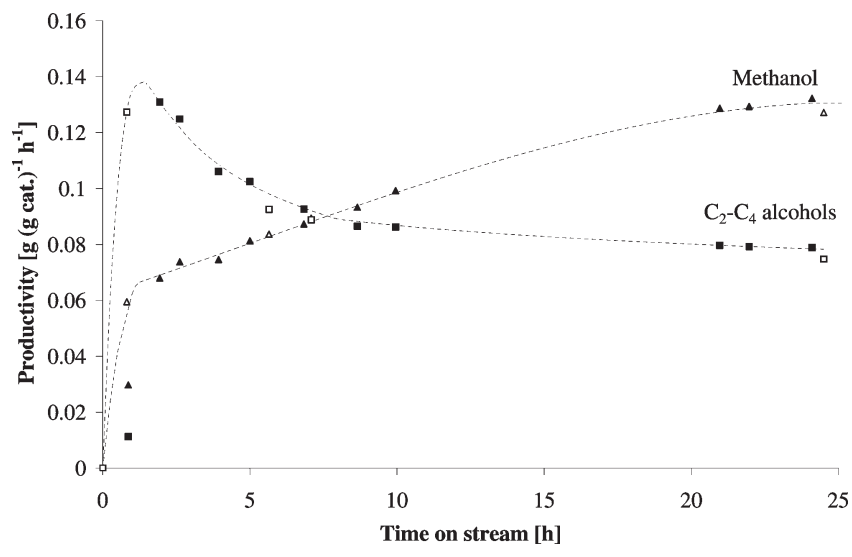

Figure 12. Production rates of methanol and $\mathrm{C}_{2}-\mathrm{C}_{4}$ alcohols over the $\mathrm{K}_{2} \mathrm{CO}_{3} / \mathrm{Co} / \mathrm{MoS}_{2} / \mathrm{C}$ catalyst as a function of the time on stream. The open symbols are for a freshly sulfided catalyst. The filled symbols are for a freshly sulfided catalyst that at $325^{\circ} \mathrm{C}$ and $1 \mathrm{~atm}$ has been exposed to 6115 ppmv $\mathrm{NH}_{3}$ in $\mathrm{H}_{2}$ for 90 min prior to the catalytic test. The experimental conditions are $T=326 \pm 1{ }^{\circ} \mathrm{C}, P=100 \mathrm{bar}$, and GHSV $=$ $5525 \mathrm{~h}^{-1}$. Feed: $49 \pm 1 \mathrm{vol} \% \mathrm{H}_{2}$ and $51 \pm 1 \mathrm{vol} \% \mathrm{CO}$.

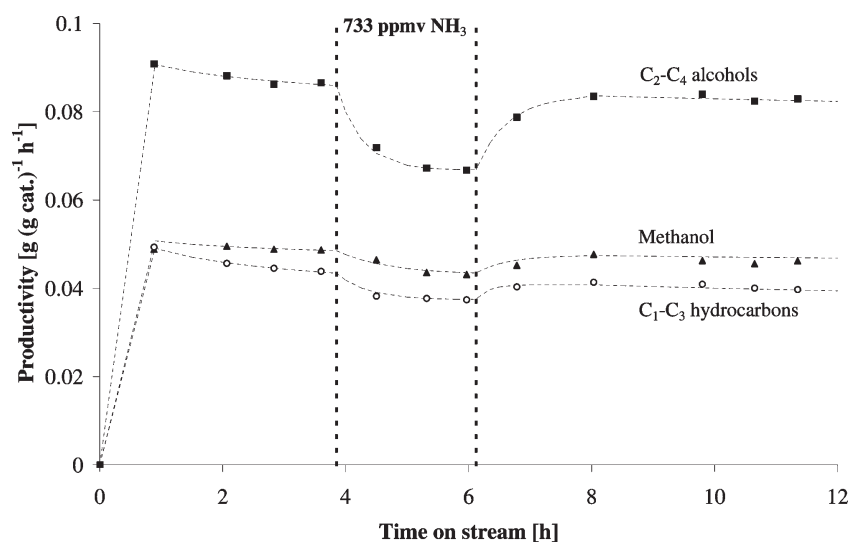

Figure 13. Production rates of methanol, $\mathrm{C}_{2}-\mathrm{C}_{4}$ alcohols and $\mathrm{C}_{1}-\mathrm{C}_{3}$ hydrocarbons as functions of the time on stream with $144 \mathrm{ppmv}_{2} \mathrm{~S}$ in the syngas. After $3.9 \mathrm{~h} 733$ ppmv $\mathrm{NH}_{3}$ is added to the syngas feed, and the $\mathrm{NH}_{3}$ addition is maintained for $2.3 \mathrm{~h}$. The experimental conditions are $T=327^{\circ} \mathrm{C}, P=100 \mathrm{bar}$, and GHSV $=5350 \mathrm{~h}^{-1}$. Feed: $49 \pm 1 \mathrm{vol} \%$ $\mathrm{H}_{2}, 51 \pm 1$ vol \% CO, and $144 \mathrm{ppmv}_{2} \mathrm{~S}$.

is similar to the drop in the total alcohol production rate. The investigations in a sulfur-containing atmosphere also indicate a largely reversible effect of ammonia. Figure 13 indicates that $2 \mathrm{~h}$ after the $\mathrm{NH}_{3}$ exposure has been discontinued the production rates of alcohols and hydrocarbons fall on the trajectory found by extrapolation of the data points obtained before the $\mathrm{NH}_{3}$ exposure. It should be pointed out that the exposure to ammonia is shorter in the experiment conducted with $\mathrm{H}_{2} \mathrm{~S}$ in the syngas than in the experiment without $\mathrm{H}_{2} \mathrm{~S}$, but it appears that the deactivation caused by ammonia is less severe in the presence of $\mathrm{H}_{2} \mathrm{~S}$. As previously discussed, the presence of $\mathrm{H}_{2} \mathrm{~S}$ in the syngas modifies the activity of the catalyst, and it is also possible that the presence of hydrogen sulfide modulates the effect that ammonia has upon the catalyst. With $\mathrm{H}_{2} \mathrm{~S}$ in the syngas the selectivity is also largely unaffected by the ammonia poisoning. This is illustrated in Figure 14, which shows the CO conversion and the $\mathrm{CO}_{2}$-free alcohol selectivity as functions of the time on 


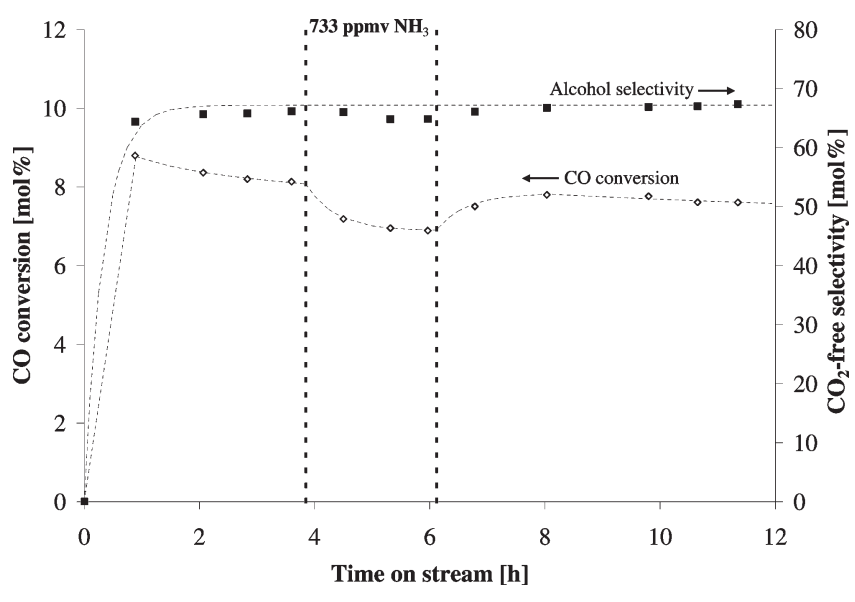

Figure 14. $\mathrm{CO}$ conversion and $\mathrm{CO}_{2}$-free alcohol selectivity as functions of the time on stream with $144 \mathrm{ppmv}_{2} \mathrm{~S}$ in the syngas. After $3.9 \mathrm{~h} 733$ ppmv $\mathrm{NH}_{3}$ is added to the syngas feed, and the $\mathrm{NH}_{3}$ addition is maintained for $2.3 \mathrm{~h}$. The experimental conditions are given in the caption of Figure 13.

stream during the $\mathrm{NH}_{3}$-poisoning experiment in an $\mathrm{H}_{2} \mathrm{~S}$-containing syngas. Figure 14 illustrates that there is only a slight reduction in the alcohol selectivity when the catalyst is exposed to ammonia.

LaVopa and Satterfield ${ }^{85}$ studied the poisoning effect of basic nitrogen compounds on the hydrotreating activity of an $\mathrm{Ni}$ / $\mathrm{MoS}_{2} / \mathrm{Al}_{2} \mathrm{O}_{3}$ catalyst. These authors ${ }^{85}$ observed that the fractional loss of activity, $\theta$, could be determined with the same expression as the one derived from a Langmuir isotherm describing the fractional surface coverage of the basic inhibitor. In this way the fractional loss of activity can be described in terms of the partial pressure of ammonia, $p_{\mathrm{NH}_{3}}$, and the ammonia adsorption equilibrium constant, $\mathrm{K}_{\mathrm{NH}_{3}}$ :

$$
\theta=\frac{p_{\mathrm{NH}_{3}} K_{\mathrm{NH}_{3}}}{1+p_{\mathrm{NH}_{3}} K_{\mathrm{NH}_{3}}}
$$

For ammonia LaVopa and Satterfield ${ }^{85}$ determined a value of $K_{\mathrm{NH}_{3}}=0.048 \mathrm{kPa}^{-1}$ for the adsorption equilibrium constant. With the presently employed partial pressure of ammonia, this would correspond to a fractional activity loss of $26 \%$. For the experiment with 144 ppmv $\mathrm{H}_{2} \mathrm{~S}$ in the syngas the predicted decline in the activity corresponds relatively well to the observed loss of activity $\left(23 \%\right.$ for $\mathrm{C}_{2}-\mathrm{C}_{4}$ alcohols, $19 \%$ for $\mathrm{C}_{1}-\mathrm{C}_{4}$ alcohols, and $15 \%$ for $\mathrm{C}_{1}-\mathrm{C}_{3}$ hydrocarbons). This may be related to the fact that the poisoning experiments by LaVopa and Satterfield ${ }^{85}$ also were conducted in the presence of hydrogen sulfide. The present results could certainly suggest that the presence of $\mathrm{H}_{2} \mathrm{~S}$ in the syngas influences the catalyst response to ammonia. The $41 \%$ activity loss observed in the absence of $\mathrm{H}_{2} \mathrm{~S}$ would correspond to an ammonia adsorption coefficient of $\mathrm{K}_{\mathrm{NH}_{3}}=$ $0.094 \mathrm{kPa}^{-1}$, but it would be imprudent to rely on a coefficient determined with only one data point. It is difficult to know if the fractional decline in the catalytic activity actually does correspond to the surface coverage of ammonia, although the fact that the loss of activity can be expressed in the same way as for a Langmuir isotherm does support this notion. If this is the case, the poisoning effect of ammonia on the alcohol synthesis catalyst can be explained by a general and largely reversible site blocking.

The observed deactivation is presumably not limited to ammonia. It is quite likely that other basic nitrogen compounds would have a qualitatively similar effect upon the catalyst, although the poisoning by other nitrogen compounds may not be as reversible, as seen for $\mathrm{NH}_{3}$. For thiophene hydrodesulfurization, LaVopa and Satterfield ${ }^{85}$ observed that the poisoning effect of numerous basic nitrogen compounds (including ammonia) correlated well with the gas phase proton affinities of the nitrogen compounds. In line with this observation, it has for pyridine been observed ${ }^{86,87}$ that the adsorption on $\mathrm{MoS}_{2}$ is related to strongly bound pyridinium ions formed in a protonation of pyridine. It is very likely that the poisoning effect of ammonia in the same way stems from adsorbed ammonium ions formed by a protonation of ammonia. In hydrotreating reactions it has been reported ${ }^{87}$ that it is especially the hydrogenation pathway which is poisoned by basic nitrogen compounds. Such a poisoning with pyridine has even been actively used to selectively diminish olefin hydrogenation during hydrodesulfurization reactions. ${ }^{88}$ In alcohol synthesis the ammonia poisoning appears to have only a very limited bearing on the selectivity, and the inhibition of the hydrogenation pathway does not appear to favor the production of either alcohols or hydrocarbons. It is possible that poisoning with another base such as pyridine could affect the selectivity, but the $\mathrm{NH}_{3}$ poisoning does not favor a specific product through a selective poisoning. This may be related to the fact that the alcohol formation and the hydrocarbon formation both require hydrogenation reactions.

The present work has focused on how $\mathrm{NH}_{3}$ affects the catalytic activity. Another potentially problematic issue related to operation in ammonia-containing syngas is, however, that nitrogen species (for example, amines) could be incorporated into the liquid alcohol product. Such an incorporation of nitrogen compounds might be problematic for the use of the alcohol product. Since no experiments were made with condensation and analysis of the liquid alcohol product, it is not possible to say whether and to what extent such an incorporation of nitrogen species occurs.

\section{CONCLUSION}

In this work it has been investigated how the feed composition and impurities in the feed influence the catalytic conversion of syngas into higher alcohols over a $\mathrm{K}_{2} \mathrm{CO}_{3} / \mathrm{Co} / \mathrm{MoS}_{2} / \mathrm{C}$ catalyst. This includes what bearing the water content in the syngas has on the catalytic properties and how $\mathrm{NH}_{3}$, a potential impurity in the syngas, affects the activity of the sulfide. It has also been investigated how the $\mathrm{H}_{2} / \mathrm{CO}$ ratio in a sulfur-free syngas influences the catalytic properties.

In a sulfur-free syngas the production rate of $\mathrm{C}_{2}-\mathrm{C}_{4}$ alcohols is at the presently employed conditions $\left(100 \mathrm{bar}, 326^{\circ} \mathrm{C}, 2600\right.$ $\mathrm{h}^{-1}$ ) observed to be optimal with an equimolar mixture of $\mathrm{CO}$ and $\mathrm{H}_{2}$, while the production rate of methanol increases with an increasing $\mathrm{H}_{2} / \mathrm{CO}$ ratio. The production of $\mathrm{C}_{1}-\mathrm{C}_{3}$ hydrocarbons largely follows the production of higher alcohols. The increasing methanol production leads to a gradual increase in the overall alcohol selectivity with an increasing hydrogen content in the feed. At the highest $\mathrm{H}_{2} / \mathrm{CO}$ ratios investigated $\left(\mathrm{H}_{2} / \mathrm{CO}=3-6 \mathrm{~mol} / \mathrm{mol}\right)$, the methanol production rate does begin to stagnate. This stagnation is most likely related to the fact that the methanol synthesis here draws near its equilibrium boundary.

Both with and without $\mathrm{H}_{2} \mathrm{~S}$ in the syngas it is observed that addition of water to the syngas feed lowers the production rates of both hydrocarbons and higher alcohols. The presence of $\mathrm{H}_{2} \mathrm{O}$ 
especially hampers the production of higher species, and this shifts the selectivity toward the $\mathrm{C}_{1}$ products methanol and methane. The synthesis activity declines with $\mathrm{H}_{2} \mathrm{O}$ added to the feed, but the $\mathrm{CO}$ conversion is actually increased by the cofeeding of water, since the $\mathrm{H}_{2} \mathrm{O}$ in the feed undergoes an essentially complete shift into $\mathrm{H}_{2} / \mathrm{CO}_{2}$.

Ammonia causes a general and largely reversible poisoning of the catalyst. In a sulfur-free syngas it is at the presently employed conditions $\left(326{ }^{\circ} \mathrm{C}, 100 \mathrm{bar}, 5525 \mathrm{~h}^{-1}, 49\right.$ vol \% $\mathrm{H}_{2}, 51$ vol \% $\mathrm{CO})$ observed that addition of $741 \mathrm{ppmv} \mathrm{NH}_{3}$ to the feed causes a $41 \%$ reduction in the production rates of both alcohols and hydrocarbons. Both with and without $\mathrm{H}_{2} \mathrm{~S}$ in the syngas, it is observed that the original behavior largely is restored once ammonia is removed from the feed. Since the presence of $\mathrm{NH}_{3}$ essentially causes the same relative drop in the production rates of both alcohols and hydrocarbons, the selectivity is largely unaffected by the $\mathrm{NH}_{3}$ poisoning.

\section{AUTHOR INFORMATION}

\section{Corresponding Author}

*E-mail: aj@kt.dtu.dk.

\section{ACKNOWLEDGMENT}

The present work is financed by The Technical University of Denmark, Haldor Topsøe A/S, and the Danish Research Council for Technology and Production under Project No. 274-07-0445. We thank Haldor Topsøe A/S for providing the catalyst used in the experiments.

\section{REFERENCES}

(1) Herman, R. G. Advances in catalytic synthesis and utilization of higher alcohols. Catal. Today 2000, 55, 233-245.

(2) Keller, J. L. Alcohols as motor fuel?. Hydrocarbon Process. 1979, $58,127-138$.

(3) Wender, I. Reactions of synthesis gas. Fuel Process. Technol. 1996, $48,189-297$.

(4) Osten, D. W.; Sell, N. J. Methanol-gasoline: Blending agents to prevent phase separation. Fuel 1983, 62, 268-270.

(5) Green, G. J.; Yan, T. Y. Water tolerance of gasoline-methanol blends. Ind. Eng. Chem. Res. 1990, 29, 1630-1635.

(6) Smith, K. J.; Anderson, R. B. The higher alcohol synthesis over promoted $\mathrm{Cu} / \mathrm{ZnO}$ catalysts. Can. J. Chem. Eng. 1983, 61, 40-45.

(7) Nunan, J. G.; Bogdan, C. E.; Klier, K.; Smith, K. J.; Young, C.-W.; Herman, R. G. Higher alcohol and oxygenate synthesis over cesiumdoped $\mathrm{Cu} / \mathrm{ZnO}$ catalysts. J. Catal. 1989, 116, 195-221.

(8) Nunan, J. G.; Bogdan, C. E.; Klier, K.; Smith, K. J.; Young, C.-W.; Herman, R. G. Methanol and $\mathrm{C}_{2}$ oxygenate synthesis over cesium doped $\mathrm{Cu} / \mathrm{ZnO}$ and $\mathrm{Cu} / \mathrm{ZnO} / \mathrm{Al}_{2} \mathrm{O}_{3}$ catalysts: A study of selectivity and ${ }^{13} \mathrm{C}$ incorporation patterns. J. Catal. 1988, 113, 410-433.

(9) Courty, P.; Durand, D.; Freund, E.; Sugier, A. $\mathrm{C}_{1}-\mathrm{C}_{6}$ alcohols from synthesis gas on copper-cobalt catalysts. J. Mol. Catal. 1982, $17,241-254$.

(10) Courty, P.; Chaumette, P.; Rimbault, C.; Travers, P. Production of methanol-higher alcohol mixtures from natural gas via syngas. Oil Gas Sci. Technol. 1990, 45, 561-578.

(11) Dalmon, J. A.; Chaumette, P.; Mirodatos, C. Higher alcohols synthesis on cobalt based model catalysts. Catal. Today 1992, $15,101-127$.

(12) Bhasin, M. M.; Bartley, W. J.; Ellgen, P. C.; Wilson, T. P. Synthesis gas conversion over supported rhodium and rhodium-iron catalysts. J. Catal. 1978, 54, 120-128.

(13) Ichikawa, M. Catalysis by supported metal crystallites from carbonyl clusters. II. Catalytic ethanol synthesis from $\mathrm{CO}$ and $\mathrm{H}_{2}$ under atmospheric pressure over supported rhodium crystallites prepared from $\mathrm{Rh}$ carbonyl clusters deposited on $\mathrm{TiO}_{2}, \mathrm{ZrO}_{2}$, and $\mathrm{La}_{2} \mathrm{O}_{3}$. Bull. Chem. Soc. Jpn. 1978, 51, 2273-2277.

(14) Tronconi, E.; Lietti, L.; Forzatti, P.; Pasquon, I. Higher alcohol synthesis over alkali metal-promoted high-temperature methanol catalysts. Appl. Catal. 1989, 47, 317-333.

(15) Tronconi, E.; Lietti, L.; Groppi, G.; Forzatti, P.; Pasquon, I. Mechanistic kinetic treatment of the chain growth process in higher alcohol synthesis over a Cs-promoted $\mathrm{Zn}-\mathrm{Cr}-\mathrm{O}$ catalyst. J. Catal. 1992, 135, 99-114.

(16) Fattore, V.; Notari, B.; Paggini, A.; Lagana, V. (Snamprogetti S. p.A.). U.S. Patent 4,513,100, 1985.

(17) Forzatti, P.; Tronconi, E.; Pasquon, I. Higher alcohol synthesis. Catal. Rev. 1991, 33, 109-168.

(18) Quarderer, G. J. Mixed Alcohols From Synthesis Gas. 78th AIChE Spring National Meeting, New Orleans, LA, USA; 1986; Paper 25a.

(19) Murchison, C. B.; Conway, M. M.; Stevens, R. R.; Quarderer, G. J. Mixed alcohols from syngas over moly catalysts. In Proceedings of the 9th International Congress of Catalysis; Phillips, M. J., Ternan, M., Eds.; Chemical Institute of Canada: Ottawa, 1988; pp 626-633.

(20) Santiesteban, J. G.; Bogdan, C. E.; Herman, R. G.; Klier, K. Mechanism of $\mathrm{C}_{1}-\mathrm{C}_{4}$ alcohol synthesis over Alkali/MoS $\mathrm{M}_{2}$ and Alkali/ $\mathrm{Co} / \mathrm{MoS}_{2}$ Catalysts. In Proceedings of the 9th international congress of catalysis; Phillips, M. J., Ternan, M., Eds.; Chemical Institute of Canada: Ottawa, 1988; pp 561-568.

(21) Stevens, R. R.; Conway, M. M. (Dow Chemical Co.). U.S. Patent 4,831,060, 1989.

(22) Dianis, W. P. Characterization of metal sulfide FischerTropsch catalysts by temperature programmed desorption. Appl. Catal. 1987, 30, 99-121.

(23) Liu, Z.; Li, X.; Close, M. R.; Kugler, E. L.; Petersen, J. L.; Dadyburjor, D. B. Screening of alkali-promoted vapor-phase-synthesized molybdenum sulfide catalysts for the production of alcohols from synthesis gas. Ind. Eng. Chem. Res. 1997, 36, 3085-3093.

(24) Bian, G.; Fan, L.; Fu, Y.; Fujimoto, K. Mixed alcohol synthesis from syngas on sulfided K-Mo-based catalysts: Influence of support acidity. Ind. Eng. Chem. Res. 1998, 37, 1736-1743.

(25) Gang, L.; Chengfang, Z.; Yanqing, C.; Zhibin, Z.; Yianhui, N.; Linjun, C.; Fong, Y. Synthesis of mixed alcohols from $\mathrm{CO}_{2}$ contained syngas on supported molybdenum sulfide catalysts. Appl. Catal., A 1997, 150, 243-252.

(26) Qi, H.; Li, D.; Yang, C.; Ma, Y.; Li, W.; Sun, Y.; Zhong, B. Nickel and manganese co-modified $\mathrm{K} / \mathrm{MoS}_{2}$ catalyst: High performance for higher alcohols synthesis from $\mathrm{CO}$ hydrogenation. Catal. Commun. 2003, 4, 339-342.

(27) Gunturu, A. K.; Kugler, E. L.; Cropley, J. B.; Dadyburjor, D. B. A kinetic model for the syntheis of high-molecular-weight alcohols over a sulfided Co-K-Mo/C catalyst. Ind. Eng. Chem. Res. 1998, 37, 2107-2115.

(28) Spencer, D. F.; Gluckman, M. J.; Alpert, S. B. Coal gasification for electric power generation. Science 1982, 215, 1571-1576.

(29) Larson, E. D.; Tingjin, R. Synthetic fuel production by indirect coal liquefaction. Energy Sustainable Dev. 2003, 7, 79-102.

(30) Williams, R. H.; Larson, E. D.; Katofsky, R. E.; Chen, J. Methanol and hydrogen from biomass for transportation. Energy Sustainable Dev. 1995, 1, 18-34.

(31) Tijmensen, M. J. A.; Faaij, A. P. C.; Hamelinck, C. N.; van Hardeveld, M. R. M. Exploration of the possibilities for production of Fischer-Tropsch liquids and power via biomass gasification. Biomass Bioenergy 2002, 23, 129-152.

(32) Herman, R. G. Classical and non-classical routes for alcohol synthesis. Stud. Surf. Sci. Catal. 1991, 64, 265-349.

(33) Higman, C.; van der Burgt, M. Gasification; Gulf Professional Publishing: USA, 2003.

(34) Salo, K.; Horvath, A.; Patel, J. Pressurized Gasification of Biomass. Presented at the International Gas Turbine \& Aeroengine Congress \& Exhibition, Stockholm, Sweden, 1998. 
(35) Torres, W.; Pansare, S.; Goodwin, J. G., Jr. Hot gas removal of tars, ammonia, and hydrogen sulfide from biomass gasification gas. Catal. Rev.—Sci. Eng. 2007, 49, 407-456.

(36) Supp, E. How To Produce Methanol from Coal; Springer-Verlag: Berlin, 1990.

(37) Christensen, J. M.; Mortensen, P. M.; Trane, R.; Jensen, P. A.; Jensen, A. D. Effects of $\mathrm{H}_{2} \mathrm{~S}$ and process conditions in the synthesis of mixed alcohols from syngas over alkali promoted cobalt-molybdenum sulfide. Appl. Catal., A 2009, 366, 29-43.

(38) Li, X.; Feng, L.; Liu, Z.; Zhong, B.; Dadyburjor, D. B.; Kugler, E. L. Higher alcohols from synthesis gas using carbon-supported doped molybdenum based catalysts. Ind. Eng. Chem. Res. 1998, 37, 3858-3863.

(39) Bogdan, C. E.; Nunan, J. G.; Santiesteban, J. G.; Herman, R. G.; Klier, K. Deactivation studies of the $\mathrm{Cs} / \mathrm{Cu} / \mathrm{ZnO}$ and Alkali/ $\mathrm{MoS}_{2}$ alcohol synthesis catalysts. Stud. Surf. Sci. Catal. 1988, 38, 745-760.

(40) Leppälahti, J.; Koljonen, T. Nitrogen evolution from coal, peat and wood during gasification: Literature review. Fuel Process. Technol 1995, 43, 1-45.

(41) Leppälahti, J. Formation and behaviour of nitrogen compounds in an IGCC process. Bioresour. Technol. 1993, 46, 65-70.

(42) Christensen, J. M.; Jensen, P. A.; Schiødt, N. C.; Jensen, A. D. Coupling of alcohols over alkali-promoted cobalt-molybdenum sulfide. ChemCatChem 2010, 2, 523-526.

(43) Rasmussen, C. L.; Hansen, J.; Marshall, P.; Glarborg, P. Experimental measurements and kinetic modeling of $\mathrm{CO} / \mathrm{H}_{2} / \mathrm{O}_{2} /$ $\mathrm{NO}_{\mathrm{x}}$ conversion at high pressure. Int. J. Chem. Kinet. 2008, 40, 454-480.

(44) Soave, G. Equilibrium constants from a modified RedlichKwong equation of state. Chem. Eng. Sci. 1972, 27, 1197-1203.

(45) Redlich, O.; Kwong, J. N. S. On the thermodynamics of solutions. V. An equation of state. Fugacities of gaseous solutions. Chem. Rev. 1949, 44, 233-244.

(46) Elliot, J. R.; Lira, C. T. Introductory Chemical Engineering Thermodynamics; Prentice Hall: New Jersey, 1998.

(47) Graaf, G. H.; Sijtsema, P. J. J. M.; Stamhuis, E. J.; Joosten, G. E. H. Chemical equilibria in methanol synthesis. Chem. Eng. Sci. 1986, $41,2883-2890$.

(48) Smith, J. M.; Van Ness, H. C.; Abbott, M. M. Introduction to Chemical Engineering Thermodynamics; McGraw-Hill: New York, 1996.

(49) Handbook of Chemistry and Physics; Lide, D. R., Ed.; CRC Press: Boca Raton, FL, USA, 1997.

(50) Reid, R. C.; Prausnitz, J. M.; Sherwood, T. K. Properties of Gases and Liquids; McGraw-Hill: New York, 1977.

(51) Chueh, P. L.; Prausnitz, J. M. Vapor-liquid equilibria at high pressures. Vapor-phase fugacity coefficients in nonpolar and quantumgas mixtures. Ind. Eng. Chem. Fundam. 1967, 6, 492-498.

(52) Tsonopoulos, C. An empirical correlation of second virial coefficients. AIChE J. 1974, 20, 263-272.

(53) Park, T. Y.; Nam, I.-S.; Kim, Y. G. Kinetic analysis of mixed alcohol synthesis from syngas over $\mathrm{K} / \mathrm{MoS}_{2}$ catalyst. Ind. Eng. Chem. Res. $1997,36,5246-5257$.

(54) Youchang, X.; Naasz, B. M.; Somorjai, G. A. Alcohol synthesis from $\mathrm{CO}$ and $\mathrm{H}_{2}$ over molybdenum sulfide. The effect of pressure and promotion by potassium carbonate. Appl. Catal. 1986, 27, 233-241.

(55) Bolton, L. V.; Gracey, B. P. (BP Chemicals Ltd.). WO Patent 2007/138300A1, 2007.

(56) Stevens, R. R. (Dow Chemical Co.). U.S. Patent 4,752,623, 1988.

(57) Quarderer, G. J.; Cochran, G. A. (Dow Chemical Co.). U.S. Patent 4,749,724, 1988.

(58) Zhang, J.; Wang, Y.; Chang, L. Sulfide catalyst for methanol synthesis, its reactivity and characterization. I. Catalyst preparation and catalytic properties. Appl. Catal., A 1995, 126, L205-L218.

(59) Klier, K.; Herman, R. G.; Nunan, J. G.; Smith, K. J.; Bogdan, C. E.; Young, C.-W.; Santiesteban, J. G. Mechanism of methanol and higher oxygenate synthesis. Stud. Surf. Sci. Catal. 1988, 36, 109-125.

(60) Barin, I.; Platzki, G. Thermochemical Data of Pure Substances; VCH Verlag: Weinheim, Germany, 1995.
(61) Ewell, R. H. Calculation of chemical equilibrium at high pressures. Ind. Eng. Chem. 1940, 32, 147-153.

(62) Thomas, W. J.; Portalski, S. Thermodynamics in methanol synthesis. Ind. Eng. Chem. 1958, 50, 967-970.

(63) von Wettberg, E. F., Jr.; Dodge, B. F. The methanol equilibrium. Ind. Eng. Chem. 1930, 22, 1040-1046.

(64) Newton, R. H.; Dodge, B. F. The Equilibrium between Carbon Monoxide, Hydrogen, Formaldehyde and Methanol. II. The Reaction $\mathrm{CO}+2 \mathrm{H}_{2} \leftrightharpoons \mathrm{CH}_{3}$ OH. J. Am. Chem. Soc. 1934, 56, 1287-1291.

(65) Subramani, V.; Gangwal, S. K. A review of recent literature to search for an efficient catalytic process for the conversion of syngas to ethanol. Energy Fuels 2008, 22, 814-839.

(66) Mawson, S.; McCutchen, S.; Lim, P. K.; Roberts, G. W. Thermodynamics of higher alcohol synthesis. Energy Fuels 1993, 7, 257-267.

(67) Qin, Z.; Liu, J.; Wang, J. Solvent effects on higher alcohol synthesis under supercritical conditions: A thermodynamic consideration. Fuel Process. Technol. 2004, 85, 1175-1192.

(68) Chinchen, G. C.; Denny, P. J.; Parker, D. G.; Short, G. D.; Spencer, M. S.; Waugh, K. C.; Whan, D. A. The activity of Cu-ZnO- $\mathrm{Al}_{2} \mathrm{O}_{3}$ methanol synthesis catalysts. Prepr. Pap.-Am. Chem. Soc., Div. Fuel Chem. 1984, $29,178-188$.

(69) Chinchen, G. C.; Denny, P. J.; Parker, D. G.; Spencer, M. S.; Whan, D. A. Mechanism of methanol synthesis from $\mathrm{CO}_{2} / \mathrm{CO} / \mathrm{H}_{2}$ mixtures over Copper/Zinc Oxide/Alumina catalysts: Use of ${ }^{14} \mathrm{C}$-labelled reactants. Appl. Catal. 1987, 30, 333-338.

(70) Kagan, Y. B.; Liberov, L. G.; Slivinskii, E. V.; Loktev, S. M.; Lin, G. I.; Rozovskii, A. Y.; Bashkirov, A. N. Mechanism of methanol synthesis from carbon dioxide and hydrogen. Dokl. Chem. (Engl. Transl.) 1975, 221, 254-256.

(71) Kagan, Y. B.; Rozovskii, A. Y.; Liberov, L. G.; Slivinskii, E. V.; Lin, G. I.; Loktev, S. M.; Bashkirov, A. N. Study of the mechanism of the synthesis of methanol from carbon monoxide and hydrogen using the radioactive carbon isotope ${ }^{14} \mathrm{C}$. Dokl. Chem. (Engl. Transl.) 1975, 224, 598-601.

(72) Quarderer, G. J.; Cochran, G. A. (Dow Chemical Co.). Eur. Patent 0,119,609, 1984

(73) British Coal Research Establishment. Synthesis of Chemical Feedstocks and Intermediates; Final Report ECSC No. 7220-EC/824; 1987.

(74) Lauritsen, J. V.; Kibsgaard, J.; Helveg, S.; Topsøe, H.; Clausen, B. S.; Lægsgaard, E.; Besenbacher, F. Size-dependent structure of $\mathrm{MoS}_{2}$ nanocrystals. Nat. Nanotechnol. 2007, 2, 53-58.

(75) Lauritsen, J. V.; Bollinger, M. V.; Lægsgaard, E.; Jacobsen, K. W.; Nørskov, J. K.; Clausen, B. S.; Topsøe, H.; Besenbacher, F. Atomic scale insight into structure and morphology changes of $\mathrm{MoS}_{2}$ nanoclusters in hydrotreating catalysts. J. Catal. 2004, 221, $510-522$.

(76) Badawi, M.; Cristol, S.; Paul, J. F.; Payen, E. DFT study of furan adsorption over stable molybdenum sulfide catalyst under HDO conditions. C. R. Chim. 2009, 12, 754-761.

(77) Karolewski, M. A.; Cavell, R. G. SIMS study of Cs/ $\mathrm{MoS}_{2}(0001)$ II. Chemisorption of $\mathrm{O}_{2}, \mathrm{H}_{2} \mathrm{O}, \mathrm{HCOOH}, \mathrm{CO}_{2}$ and $\mathrm{CS}_{2}$. Surf. Sci. 1989, 219, 261-276.

(78) Laurent, E.; Delmon, B. Influence of water in the deactivation of a sulfided $\mathrm{NiMo} / \gamma-\mathrm{Al}_{2} \mathrm{O}_{3}$ catalyst during hydrodeoxygenation. J. Catal. 1994, 146, 281-291.

(79) Machemer, H. Über die Guerbetsche Reaktion und ihre technische Bedeutung. Angew. Chem. 1952, 64, 213-220.

(80) Hilmen, A. M.; Xu, M.; Gines, M. J. L.; Iglesia, E. Synthesis of higher alcohols on copper catalysts supported on alkali-promoted basic oxides. Appl. Catal., A: Gen. 1998, 169, 355-372.

(81) Burk, P. L.; Pruett, R. L.; Campo, K. S. The rhodium-promoted Guerbet reaction Part I. Higher alcohols from lower alcohols. J. Mol. Catal. 1985, 33, 1-14.

(82) Calafat, A.; Laine, J. Factors affecting the carbonylation of methanol over sulfided CoMo/C catalysts at atmospheric pressure. Catal. Lett. 1994, 28, 69-77. 
(83) Calafat, A.; Laine, J. High pressure reaction of methanol with $\mathrm{CO}$ or $\mathrm{CO}+\mathrm{H}_{2}$ catalyzed by sulfided CoMo/C. Appl. Catal., A 1995, $133,67-79$.

(84) Chen, Y. Y.; Zhao, X.; Wen, X. D.; Shi, X. R.; Dong, M.; Wang, J.; Jiao, H. Mechanistic aspect of ethanol synthesis from methanol under $\mathrm{CO}$ hydrogenation condition on $\mathrm{MoS}_{\mathrm{x}}$ cluster model catalysts. J. Mol. Catal. A 2010, 329, 77-85.

(85) LaVopa, V.; Satterfield, C. N. Poisoning of thiophene hydrodesulfurization by nitrogen compounds. J. Catal. 1988, 110, 375-387.

(86) Temel, B.; Tuxen, A. K.; Kibsgaard, J.; Topsøe, N.-Y.; Hinnemann, B.; Knudsen, K. G.; Topsøe, H.; Lauritsen, J. V.; Besenbacher, F. Atomicscale insight into the origin of pyridine inhibition of $\mathrm{MoS}_{2}$-based hydrotreating catalysts. J. Catal. 2010, 271, 280-289.

(87) Logadóttir, Á.; Moses, P. G.; Hinnemann, B.; Topsøe, N.-Y.; Knudsen, K. G.; Topsøe, H.; Nørskov, J. K. A density functional study of inhibition of the HDS hydrogenation pathway by pyridine, benzene, and $\mathrm{H}_{2} \mathrm{~S}$ on $\mathrm{MoS}_{2}$-based catalysts. Catal. Today 2006, 111, 44-51.

(88) Hatanaka, S. Hydrodesulfurization of selective catalytic cracked gasoline. Catal. Surv. Asia 2005, 9, 87-93. 